University of Wollongong

Research Online

Faculty of Social Sciences - Papers (Archive) Faculty of Arts, Social Sciences \& Humanities

$1-1-2020$

\title{
Loneliness among people with substance use problems: A narrative systematic review
}

Isabella Ingram

University of Wollongong, ii841@uowmail.edu.au

Peter James Kelly

University of Wollongong, pkelly@uow.edu.au

Frank P. Deane

University of Wollongong, fdeane@uow.edu.au

Amanda Baker

Melvin Goh

University of Wollongong, mcwg178@uowmail.edu.au

See next page for additional authors

Follow this and additional works at: https://ro.uow.edu.au/sspapers

Part of the Education Commons, and the Social and Behavioral Sciences Commons

Research Online is the open access institutional repository for the University of Wollongong. For further information contact the UOW Library: research-pubs@uow.edu.au 


\title{
Loneliness among people with substance use problems: A narrative systematic review
}

\begin{abstract}
2020 Australasian Professional Society on Alcohol and other Drugs Issues: Despite the serious implications of loneliness on health and wellbeing, little is understood about this experience across people with substance use problems. This systematic review aimed to examine: (i) correlates and predictors of loneliness; (ii) theories underpinning loneliness; (iii) methods employed to measure Ioneliness; and (iv) loneliness interventions for people with substance use problems. Approach: Empirical sources were identified from key databases for all publications preceding February 2019. Overall, 41 studies met the eligibility criteria and were included in the review. Key Findings: Findings from this review suggest that loneliness is related to poor physical and mental health, substance use, the quality of relationships, stigma and perception of ill treatment by others. Although cognitive theories have proposed cognitive patterns underlying the onset and maintenance of loneliness, they had not been investigated in relation to measurement or intervention efforts. Just one loneliness measure (UCLA Loneliness Scale) is valid for use with this population. Finally, only a single loneliness intervention had been trialled and was not found to be efficacious in reducing loneliness for people with substance use problems. Implications: Understanding possible links between loneliness and substance use and how to alleviate loneliness is important for this population in terms of their wellbeing and recovery. Conclusion: Loneliness is prevalent and experienced as problematic among people with substance use problems. Future research should focus on employing longitudinal designs, using validated, multidimensional measures of loneliness and on developing and trialling loneliness interventions that meet the specific needs of people with substance use problems.

\section{Disciplines \\ Education | Social and Behavioral Sciences}

\section{Publication Details}

Ingram, I., Kelly, P., Deane, F., Baker, A., Goh, M., Raftery, D. \& Dingle, G. (2020). Loneliness among people with substance use problems: A narrative systematic review. Drug and Alcohol Review,
\end{abstract}

\section{Authors}

Isabella Ingram, Peter James Kelly, Frank P. Deane, Amanda Baker, Melvin Goh, Dayle Raftery, and Genevieve A. Dingle 


\section{Drug and Alcohol \\ R E V I E W \\ APSAD}

\section{Loneliness amongst people with substance use problems: A narrative systematic review}

\begin{tabular}{|c|c|}
\hline Journal: & Drug and Alcohol Review \\
\hline Manuscript ID & CDAR-2019-0220.R1 \\
\hline Manuscript Type: & Review \\
\hline $\begin{array}{r}\text { Date Submitted by the } \\
\text { Author: }\end{array}$ & 10-Feb-2020 \\
\hline Complete List of Authors: & $\begin{array}{l}\text { Ingram, Isabella; University of Wollongong School of Psychology, } \\
\text { Illawarra Health and Medical Research Institute } \\
\text { Kelly, Peter; University of Wollongong School of Psychology, Illawarra } \\
\text { Health and Medical Research Institute } \\
\text { Deane, Frank; University of Wollongong School of Psychology, Illawarra } \\
\text { Health and Medical Research Institute } \\
\text { Baker, Amanda; The University of Newcastle School of Medicine and } \\
\text { Public Health } \\
\text { Goh, Melvin; University of Wollongong School of Psychology, Illawarra } \\
\text { Health and Medical Research Institute } \\
\text { Raftery, Dayle; University of Wollongong School of Psychology, Illawarra } \\
\text { Health and Medical Research Institute } \\
\text { Dingle, Genevieve; University of Queensland School of Psychology }\end{array}$ \\
\hline $\begin{array}{r}\text { Keywords (Please ensure that } \\
\text { the Keywords and a short } \\
\text { Running Head are also } \\
\text { included in the manuscript } \\
\text { file): }\end{array}$ & $\begin{array}{l}\text { Loneliness, Systematic review, Addiction, Alcohol and substance } \\
\text { dependence }\end{array}$ \\
\hline
\end{tabular}

\section{SCHOLARONE ${ }^{\text {m }}$ Manuscripts}


Running head: Review: Loneliness and substance dependence

\section{Loneliness amongst people with substance use problems: A narrative systematic review}

Isabella Ingram ${ }^{1}$, Peter J. Kelly ${ }^{1}$, Frank P. Deane ${ }^{1}$, Amanda L. Baker ${ }^{2}$, Melvin C. W. Goh ${ }^{1}$, Dayle K. Raftery ${ }^{1}$, Genevieve A. Dingle ${ }^{3}$

${ }^{1}$ Illawarra Health and Medical Research Institute and School of Psychology, University of Wollongong, Wollongong Australia

${ }^{2}$ School of Medicine and Public Health, University of Newcastle, Newcastle, Australia ${ }^{3}$ School of Psychology, University of Queensland, Brisbane, Australia

Isabella Ingram GDipProfPsych, PhD Candidate, Peter J. Kelly PhD, Head of Research, Frank P. Deane PhD, Professor, Amanda L. Baker PhD, Professor, Melvin C. W. Goh BPsycSc, PhD Candidate, Dayle K. Raftery MProfPsyc, PhD Candidate, Genevieve A. Dingle $\mathrm{PhD}$, Associate Professor.

Author for correspondence: Ms Isabella Ingram, School of Psychology, University of Wollongong, Wollongong, NSW 2500, Australia. Tel: 02 4221 4484, Email: ingram@uow.edu.au 
Running head: Review: Loneliness and substance dependence

\begin{abstract}
Issues: Despite the serious implications of loneliness on health and wellbeing, little is understood about this experience across people with substance use problems. This systematic review aimed to examine: (i) correlates and predictors of loneliness; (ii) theories underpinning loneliness; (iii) methods employed to measure loneliness; and (iv) loneliness interventions for people with substance use problems.

Approach: Empirical sources were identified from key databases for all publications preceding February 2019. Overall, 41 studies met the eligibility criteria and were included in the review.

Key Findings: Findings from this review suggest that loneliness is related to poor physical and mental health, substance use, the quality of relationships, stigma, and perception of ill treatment by others. Although cognitive theories have proposed cognitive patterns underlying the onset and maintenance of loneliness, they had not been investigated in relation to measurement or intervention efforts. Just one loneliness measure (UCLA Loneliness Scale) is valid for use with this population. Finally, only a single loneliness intervention had been trialled and was not found to be efficacious in reducing loneliness for people with substance use problems.
\end{abstract}

Implications: Understanding possible links between loneliness and substance use and how to alleviate loneliness is important for this population in terms of their wellbeing and recovery.

Conclusion: Loneliness is prevalent and experienced as problematic among people with substance use problems. Future research should focus on employing longitudinal designs, using validated, multidimensional measures of loneliness, and on developing and trialling loneliness interventions that meet the specific needs of people with substance use problems.

Keywords: loneliness, systematic review, addiction, alcohol and substance dependence 
Running head: Review: Loneliness and substance dependence

Loneliness is a global public health issue [1], predicting poor physical and mental health, and morbidity and mortality across the general population [2-5]. Loneliness is a painful emotional state resulting from a discrepancy between the relationships one perceives they have and those they desire [6]. Throughout the literature, loneliness has been considered as both a uni-dimensional construct and also a multi-dimensional construct, encompassing both social and emotional forms of loneliness [7].

Global prevalence rates of loneliness are difficult to ascertain, but it is estimated that $40 \%$ of older adults [8] and roughly one-third of people across industrialised countries experience loneliness [1]. Recent research has focused on determining those age groups, characteristics and specific populations that may be most vulnerable to experiencing loneliness [e.g. 9-11]. Reviews have concluded that loneliness is highly prevalent amongst elderly populations [12] and people living with serious mental illnesses, such as psychosis [13]. Despite the growth in loneliness research, people with substance use problems are a population that has been largely overlooked, with no reviews having been conducted in this area [14].

Illicit drug use has been deemed the most stigmatised health condition in the world, while alcohol dependence is the fourth most stigmatised condition $[15,16]$. Research across a range of populations has found that social isolation can result from the effects of stigma [1719]. While not everyone who is isolated becomes lonely, social isolation and loneliness are closely related [20]. Consequently, people with substance use problems are vulnerable to experiencing loneliness that arises from stigma and social isolation. Additionally, people with substance use problems may make and maintain relationships that meet their needs and support their active substance use but once in recovery, their social needs are likely to have changed (e.g. toward non-using contacts). When abstinent from substance use, there may be a need to avoid those situations and relationships that perpetuate ongoing substance use and 
Running head: Review: Loneliness and substance dependence

instead attempt to connect with people who support one's recovery [21]. This process is likely to increase the risk of loneliness for people recovering from substance use problems. Recent research has indicated that $79 \%$ of 316 individuals accessing treatment for substance use problems reported often feeling lonely. Additionally, this study reported that $69 \%$ of these participants agreed to the statement "loneliness has been a serious problem for me" [22]. While such findings are limited to an Australian population, they suggest loneliness is highly prevalent and problematic for people who experience substance use problems.

Loneliness research is in its infancy amongst those with substance use problems and there is a need to better understand the correlates of loneliness and the relationship between loneliness and substance use. In general community samples, both younger and older age [23], male gender [24] poorer physical and mental health [25-27], poorer quality social relationships [28] and poorer quality of life [27] have been associated with loneliness. Despite these findings across the broader literature, current research in the context of people with substance use disorders has revealed limited and conflicting findings in relation to theoretical and empirical correlates and predictors of loneliness.

Social and cognitive theories of loneliness have been most prominent in efforts to try to better understand predictors and causes of loneliness. For example, attribution theory [6] suggests that in attempts to explain the cause of their loneliness, lonely people adopt an attribution style that is internal and stable; that is, these individuals believe their loneliness is due to some shortcoming of their own (internal) and that this shortcoming is unchangeable (stable) [29-31]. Cognitive theories also describe a hypervigilance to social threat in the environment, and negative expectations of social interactions, as being central to the onset and maintenance of loneliness [26]. While these theories have been used to explain how people become lonely, very few studies have referenced these theories in the context of addiction. Preliminary research in this field suggests that that cognition may be important in 
Running head: Review: Loneliness and substance dependence

explaining loneliness $[32,33]$, yet there is little empirical research available to support this assertion. It remains unclear which specific cognitive patterns might be responsible for the onset and maintenance of loneliness for people with substance use disorders, and consequently, how to best assess and treat this problem.

Loneliness is a difficult construct to measure, with studies across other populations using a range of tools that target related social constructs, such as social isolation [34]. The University of California, Los Angeles (UCLA) Loneliness Scale [35] is the most widely used tool across the broader literature, but there remains ongoing ambiguity surrounding the dimensionality of this measure [36]. In addition, most research assessing the validity of loneliness scales is focused on college samples or the ageing population [36]. The scarcity of research with a focus on substance using populations means that questions remain about how loneliness can best be assessed and this in turn impedes research efforts to develop targeted interventions for this population.

Theory may provide guidance in addressing these needs and reviews and metaanalyses of intervention studies appear to support cognitive theories of loneliness [14, 37]. These studies have found that interventions aiming to address maladaptive social cognition were most efficacious in reducing loneliness across diverse samples, including children, adults and seniors. The impact of interventions that target social cognition for people with substance use problems is yet to be examined. In fact, little is known about the efficacy of any type of intervention in helping to reduce feelings of loneliness for this population.

Given there is little understanding of loneliness across people with substance use problems, the purpose of this review is to synthesise the existing literature. Specifically, this review aims to examine: (i) correlates and predictors of loneliness (including demographic, physical health, mental health, social variables and substance use variables); (ii) prominent theories to explain loneliness; (iii) methods to measure loneliness; and (iv) interventions that 
Running head: Review: Loneliness and substance dependence

have specifically aimed to target loneliness for people with substance use problems.

\section{Methods}

Protocol registration: The review protocol was registered with Prospero International Prospective Register of Systematic Reviews (registration number CRD42018105564) and can be accessed at https://www.crd.york.ac.uk/prospero/. The Preferred Reporting Items for Systematic Reviews and Meta-Analyses (PRISMA) Checklist [see 38] was used to guide reporting of this review.

Information sources: Empirical sources were identified from the databases PsycINFO, PubMed, CINAHL Plus, MEDLINE, Scopus, Web of Science, and The Cochrane Library (Cochrane Database of Systematic Reviews, Cochrane Central Register of Controlled Trials [CENTRAL], Cochrane Methodology Register) for all publications preceding February 2019. Search strategy: The searches were performed in April 2018 and updated in February 2019 using the search terms: "lonel*" and a range of relevant substance-related key terms (see protocol for a list of specific terms used). These terms were searched for in the abstract, title, keywords and subject of sources. Reference lists of identified sources were then screened to identify additional relevant studies.

Eligibility criteria: To be included in the review, the sources had to: (i) be published in English language; (ii) report on empirical research; (iii) report on loneliness in their results (loneliness being a research question of the study or specifically measured as part of the study); and (iv) contain a sample that consists of people with substance use problems (i.e. have a diagnosis of substance use disorder, or accessing treatment specifically for substance use problems).

Study selection: Overall, 41 studies met the eligibility criteria and were included in the review. Initial screening of titles and abstracts was undertaken by the first author, and then 
Running head: Review: Loneliness and substance dependence

identified full texts were independently screened by the first author and MG. There was a high degree of agreement between the first two reviewers, $k=0.84, P<0.001$. Discrepancies in decisions to include/exclude full-text sources were resolved through consultation with a third reviewer (DR). Figure 1 shows the literature selection process.

\section{INSERT FIGURE 1 ABOUT HERE.}

Data collection and items: The first author extracted data from the 41 studies included in the review. Data extraction included information related to: authors, the title of the study and year of publication, type of study, study setting, participant characteristics and details of: tools used to measure loneliness, theoretical discussions, demographics, substance use, physical health, mental health, social variables and/or interventions reported in relation to loneliness.

Risk of bias in studies: Two reviewers (II and MG) independently assessed the methodological quality and risk of bias of the included quantitative studies against the criteria set by the National Institutes of Health Study Quality Assessment Tools [39]. Discrepancies in ratings of study quality were resolved through discussion and use of a third reviewer (DR). Studies were assigned to one of three categories; 'good', 'fair', or 'poor' quality based on their design and conduct. Studies were deemed to be of 'good' quality if validated instruments were used (defined as instruments which had been validated for use with people who experience substance use problems), the probability of information bias and selection bias appeared to be low, follow-up (where relevant) was over a number of years (defined as being a timeframe long enough to enable a meaningful analysis to be conducted of the relationship between exposures and outcomes), and confounding variables were considered and adjusted for. The probability of low selection and information bias was determined by 
Running head: Review: Loneliness and substance dependence

inspecting the National Institutes of Health items corresponding to each type of bias. As a general rule of thumb, the fewer the number of items that were deemed a 'no', then the lower the risk of bias and better the overall study quality. The more subjective and qualitative method for assessing risk of bias was based on recommendations by Viswanathana et al. [40] and Wang et al. [41]. Qualitative studies that were included in the review were critically appraised against the 10-item Critical Appraisal Skills Programme checklist for Qualitative studies [42]. Based on the number of items coded 'no' on the Critical Appraisal Skills Programme Checklist, indicating potential risk of bias, these qualitative studies were categorised into 'good', 'fair' and 'poor' quality, with a greater number of 'no' responses indicating poorer quality (See Table S1).

Data summary and synthesis: Data were summarised based on the specified aims of the review. While the UCLA measure of loneliness was widely used across studies included in the review, a diverse range of correlational and predictor variables were present. Given the heterogeneity across these studies in terms of outcomes and methods used, as well as the small samples sizes, a narrative synthesis was conducted rather than a meta-analytic synthesis. This decision was based on the lack of robust statistical methods available for such heterogeneity, and researchers warning against performing underpowered meta-analyses [43, 44].

\section{Results}

Study selection: Of the 1628 records screened, 173 full-text studies were assessed for eligibility and 41 were included in the review. Figure 1 shows the study selection process and reasons for study exclusions at each stage of the review.

Study characteristics: Study characteristics for the 41 studies included in the review are presented in Table 1. Overall, nine of the included studies were longitudinal and 32 were 
Running head: Review: Loneliness and substance dependence

cross-sectional in design, with six of these being qualitative studies. Eleven of the included studies were dissertation theses and the remaining 30 studies were journal articles.

\section{INSERT TABLE 1}

Risk of bias of each study: Using the National Institutes of Health quality assessment tool for observational cohort and cross-sectional studies, all studies were rated as either 'good', 'fair' or 'poor' quality. Four studies were rated as 'good', 29 studies as 'fair' and 9 studies as 'poor' (see Table 1). The one quantitative study rated as being of 'good' quality was deemed to have a low risk of information and selection bias and confounding variables were controlled for [64]. The three qualitative studies that were deemed to be 'good' quality $[49,57,72]$ all appeared to present valid results that were clearly described and likely to be informative to relevant practice/policy and/or research literature. Many of the studies appeared to minimise some risk of selection or information bias, yet those that met very few of these criteria were deemed as 'poor' quality. Potential confounding factors were inconsistently assessed across studies, with just two of the cohort studies adjusting for confounding variables $[64,65]$.

\section{Synthesis of results}

Across the studies included in this review, the age of participants ranged from 11 to 98 years old, and $65 \%(n=9951)$ were males. Four studies did not report data related to the proportion of each gender in their sample. Sample sizes ranged from 8 to 652 participants across 40 of the studies included in this review. One study did not specify their sample size [79]. Of the study samples, $49 \%(n=20)$ were people who used alcohol, $20 \%(n=8)$ were people who used opiates, $12 \%(n=5)$ used a mix of drugs and alcohol, 10\% $(n=4)$ used a mix of drugs only, and 5\% $(n=2)$ did not report the substance use of their sample. The remaining 
Running head: Review: Loneliness and substance dependence

two studies consisted of a sample of people who used methamphetamines, and one sample of people who used heroin. Inpatient substance dependence treatment services were the most common study setting $(n=8)$, followed by a combination of inpatient/outpatient settings $(n=7)$, methadone maintenance settings $(n=5)$, and other outpatient substance dependence treatment services $(n=4)$. Fifteen studies used other samples, including Alcoholics Anonymous (AA) populations and inpatient and outpatient mental health services. Two studies did not specify their study setting. Loneliness prevalence was reported in five of the studies $[22,32,67,75,81]$ and ranged from $35 \%$ to $79 \%$.

Correlates and predictors of loneliness

Demographics ( $n=16$ studies): Seven studies found no relationship between demographic variables and loneliness. Nine studies $(n=56 \%)$ reported correlations with some demographic variables. Of those nine, five suggested that younger individuals were lonelier ( $n=56 \%$ of nine studies) $[46,54,65,69,70]$ and of seven examining gender, four suggested females ( $n=57 \%$ of seven studies) $[46,69,70]$ may be more likely to be lonely across this population.

Health ( $n=22$ studies): Consistent with findings across other populations, loneliness appears to be related to poor physical and mental health for people with substance use problems [e.g. 22,56,80,81]. Seven studies examined physical health variables and found that poorer sleep quality and quantity [60,67], increased pain intensity [66] and poorer self-rated physical health $[22,68,69]$ was correlated with increased loneliness. In addition, mental health indicators such as depression [22,33,75,78,80,81], self-esteem [32,52,60,68,70,80], suicidality $[53,57,83]$ and poorer wellbeing/quality of life $[22,53]$ were also related to higher loneliness across 15 studies ( $83 \%$ of 18 studies examining mental health variables).

Social and cognitive variables ( $n=15$ studies): For people with alcohol use problems, loneliness was related to dissatisfaction in the quality of their relationships $[32,33,46]$. In 
Running head: Review: Loneliness and substance dependence

addition, loneliness was consistently related to poor social support with all three studies that examined this variable finding a correlation $[52,56,75]$. Three studies also found that their samples perceived ill treatment from others $[32,56,60]$ or that they were stigmatised [48] and that these factors were related to loneliness for people with substance use problems (i.e. [48]). Aligned with the prominent cognitive theories, eight studies (53\% of 15 studies examining social and cognitive variables) reported factors such as shyness, poor self-esteem and feelings of insecurity and inferiority are associated with feelings of loneliness, suggesting that negative perceptions of the self in relation to others plays a role in the onset and/or maintenance of loneliness $[32,33,46,49,57,60,68,70]$.

Substance use variables ( $n=20$ studies): Of studies that examined substance use variables, four ( $20 \%$ of 20 studies) suggest that people use substances to avoid distressing feelings such as loneliness $[63,74,77,78]$. Five studies $(25 \%)$ that examined signs of dependence, such as frequency, severity or duration and symptoms of use, suggest that these variables are related to loneliness. When examining loneliness longitudinally, mixed findings emerged, with one study suggesting loneliness to be related to signs of substance dependence [60], and another study concluding that loneliness was not related to substance use at a twoyear follow-up [32]. No notable differences emerged in terms of the prevalence or severity of loneliness and different types of substance (i.e. alcohol or other substances) [22,81]. Perceptions of oneself and others noted above appear to ultimately result in feelings of loneliness, which in turn may be an antecedent to continued alcohol use [78] or higher alcohol consumption [60]. Aligned with these results, some studies found loneliness was a risk factor for continued opiate use [62], with opiate use reported to be a means of escaping feelings of loneliness [63]. Similar findings emerged in the one study that examined people with methamphetamine problems [74], and across people with poly-substance use problems [77]. 
Running head: Review: Loneliness and substance dependence

Additionally, studies included in the review examined participants across a range of substance use and recovery stages. Two studies (67\% of three studies) $[47,54]$ suggest that those in more acute stage of addiction (currently using/detoxification) are lonelier than those in middle and later stages of recovery, while one study found no differences [59]. Across the stages of recovery and treatment settings, common themes emerged in terms of the health, social and substance use variables that were related to loneliness. Specifically, poor sleep, poor self-rated physical health, depression, poorer self-esteem, suicidality and poorer wellbeing/quality of life were related to higher loneliness across samples that were currently using substances and those that were in recovery. Similarly, poor social support, poorer quality and fewer quantities of relationships were consistent social variables that were found to relate to loneliness across different stages of recovery and treatment settings. Finally, reports of substance use as a means of coping with, or escaping loneliness, were reported for samples that were actively using substances, and those that were in recovery.

Few studies ( $n=2,5 \%$ of 41 studies) examined the impact of substance dependence treatment on loneliness. One study [72] suggested that residing in a therapeutic community treatment setting might in fact contribute to feelings of loneliness and social distancing. This qualitative study suggested that within this treatment environment, participants became polarised, whereby alcohol users avoided illicit drug users. While this leaves questions as to the role of treatment services in impacting feelings of loneliness, stigma and social distancing might be a factor that contributes to loneliness in these settings. Targeting stigmatising attitudes of others as well as internalised stigma remains an ongoing target of policy makers and substance use treatment providers (e.g. [84]), and is evidently a necessity in order to aid in reducing feelings of loneliness for this population. Despite the research finding by Neale et al. [72] another study found some evidence to suggest that mutual support groups, such as AA groups, might be beneficial in reducing feelings of loneliness [49]. The effect of AA 
Running head: Review: Loneliness and substance dependence

might be attributed to the recovery-based social identity gained, and the positive social capital generated through involvement in AA groups [85]. Factors such as social support, feelings of acceptance and shared values that are common in mutual support groups are thought to increase a sense of belonging and reduce feelings of loneliness.

Theories of loneliness ( $n=2$ studies): Studies that describe theories of loneliness across this population are scarce. Just two studies applied theories of loneliness to their design or findings, with both of these studies discussing cognitive theories of loneliness. Akerlind and Hörnquist [32] allude to the social psychological and cognitive perspective (i.e. $[7,86-88])$. They found loneliness to be related to dissatisfaction with social relationships and to perceived negative treatment from others, and they explained these findings by referring to theory. Notably, these theories were not discussed in depth in relation to their study findings. Johnson [33] discussed her findings, that loneliness decreased with age, in relation to the Attribution Theory of loneliness [88], by suggesting that as one ages, their ability to develop realistic expectations for their relationships improves, as does their ability to overcome social inhibitions. Furthermore, Johnson [33] found that shyness predicted loneliness amongst people who used alcohol. These findings were discussed in the context of Attribution Theory by highlighting that a person's identification as 'shy' is likely to be a way to explain their relational characteristics in a way that is stable, internal and uncontrollable (consistent with Attribution Theory), which in turn decreases the likelihood of developing new relationships. Measures of loneliness ( $n=36$ studies): A range of measures were used to assess loneliness, yet very few studies used tools that had been specifically validated for use across substance dependent populations. Twelve of the 36 studies used author-developed measures to assess loneliness (33\%), while 17 (47\%) studies used measures that were developed and validated across a range of populations. Ten (28\%) studies used other psychometric tools that included items or subscales that asked about loneliness. The three final studies included in the 
Running head: Review: Loneliness and substance dependence

review $[49,62,71]$ did not specifically measure loneliness; rather loneliness was a key theme that emerged as an outcome of these qualitative studies. All measures are summarised in Table 2.

\section{INSERT TABLE 2}

While three studies ( $8 \%$ of 36 studies) set out to validate measures of loneliness for substance dependent populations $[22,50,73]$, these studies each used different tools to measure loneliness, with only one study using a multidimensional measure that captured both social and emotional forms of loneliness [22]. The UCLA measure was the most widely-used tool across studies included in this review ( $n=11,31 \%$ of 36 studies), with 'fair' to 'excellent' internal consistency, and 'fair' test-retest reliability reported across study samples (see Table 2). There was limited consistency in the reporting of psychometric properties of loneliness measures. A number of studies included in the review made reference to psychometric properties that were reported for other populations in prior studies (see Table 2 and Appendix 1 for further information). Overall, the mixed reporting of psychometrics, and mixed findings across these studies, continues to create a challenge for future researchers in the field, in terms of selection and application of loneliness measures.

Loneliness interventions ( $n=1$ study): Just one study aimed to evaluate an intervention to alleviate loneliness. Using a non-randomised trial design, Johnson [33] examined a logoanalysis intervention. This is an existential form of therapy, which was delivered in a group format for one hour per day over a period of two weeks at an inpatient alcohol treatment facility. This intervention appeared to focus on the identification of personal values, and on goal setting to pursue values-congruent activities. The study involved a treatment and a control group of all males, who were compared on measures of loneliness at post- 
Running head: Review: Loneliness and substance dependence

intervention. It was found that there were no differences in loneliness between the intervention and control groups following treatment. The non-significant results were attributed to the brief nature of the intervention (two weeks) and the broad focus of the intervention (not loneliness specific), with some participants having identified values and goals that were not social in nature. Findings from this study point to the need for more research focusing on lengthier and more targeted interventions for loneliness amongst substance dependent populations.

\section{Discussion}

This systematic review aimed to present a comprehensive overview of loneliness research conducted across substance dependent populations. Forty-one completed studies met the eligibility criteria and were included in this review. Findings from this review provide preliminary evidence to suggest that people with substance use problems are lonelier than the general population (i.e. [22]) and that females and those younger in age may be lonelier. Socioemotional selectivity theory [106] may help to explain some of these findings. This theory posits that in later life, individuals tend to cultivate their social networks in order to enhance the social and emotional gains they derive from these relationships. This theory might explain the reduced loneliness in older age groups found in some studies in this review. Findings from this review also suggest that loneliness is consistently related to poor physical and mental health for this population. Since data is predominantly correlational in nature, the causal sequence of these relationships cannot be determined. It is possible that loneliness leads to poorer health, or those experiencing poorer health become lonelier, or both.

While it remains unclear whether differences in loneliness exist based on type of substance of dependence, a consistent finding was that higher severity/duration of substance dependence is related to higher loneliness. Those studies that examined signs of substance 
Running head: Review: Loneliness and substance dependence

dependence and were longitudinal in design $(n=3)$ revealed mixed findings in relation to substance use variables and loneliness. One of these studies suggested loneliness was crosssectionally but not longitudinally related to substance use variables [32]. However, others found loneliness was longitudinally related to substance use problems [64], higher alcohol consumption, delirium and blackouts [60]. No research has clarified the causal direction or dynamics of this relationship, but it is possible that those who use substances to a greater extent (i.e. higher severity) are also those who are more likely to have difficulty maintaining relationships and/or be stigmatised in society, and ultimately become lonelier as a result of social isolation and stigma.

Overall, just two studies discussed their findings in the context of theories of loneliness. Both studies referenced cognitive theories of loneliness and provided some basis for the belief that cognition may be important in explaining loneliness amongst substance dependent people. However, neither of these studies set out to test specific theories of loneliness and the empirical basis to support these theories is lacking. Research that aims to test theories of loneliness appears to be in its infancy. Reviews and meta-analyses exploring interventions to reduce loneliness amongst a range of populations have suggested cognitive interventions as likely to be most effective in alleviating loneliness $[14,37,107,108]$. Findings from these intervention studies suggest that merely increasing social contact has little impact on feelings of loneliness, and rather 'maladaptive social cognition' or the belief one has about themselves and others in relationships, has a greater effect on the subjective feeling of loneliness [37]. Conclusions from these intervention studies lend support to the cognitive theory of loneliness proposed by Perlman and Peplau [88], yet further research is clearly warranted, particularly in field of substance dependence.

The current review revealed that very few of the measures used across the 41 studies had been validated for use with people who experience substance use problems. Only three 
Running head: Review: Loneliness and substance dependence

studies $[22,50,73]$ specifically aimed to examine psychometric properties of the loneliness measures they used. Of these studies, just one aimed to validate a multi-dimensional measure of loneliness in order to further the understanding of this construct amongst this unique population [22]. Loneliness is progressively being viewed as a multidimensional construct, which cannot be captured using single-item or uni-dimensional measures $[109,110]$. The UCLA Loneliness Scale [35] was the most commonly used tool across the studies included in this review. However, this measure does not isolate different types of loneliness that have been largely accepted across the broader loneliness literature [see 111]. While this measure had been validated for use in methadone maintenance settings, its validity across a broader range of substance dependence samples (i.e. inpatient, alcohol, amphetamines) is yet to be determined. In addition, this tool potentially poses problems with face validity. The scale adopts an indirect approach to measuring loneliness by omitting the word 'lonely', an approach that has been found to yield differences in responding compared with a direct approach [e.g. 112].

One key finding of the current review is the scarcity of studies involving interventions specifically aimed at alleviating loneliness for this population. This highlights an important future research direction, whereby interventions aimed at targeting loneliness need be developed, piloted, and rigorously tested using high quality research designs. Based on findings from this review and that of previous research in the field of loneliness [e.g. 14] interventions that target one's perceptions of themselves and others, such as how they are treated, the support they receive and their self-esteem might be of benefit for this population. Research efforts that seek to identify the specific cognitions and social variables to be the focus of interventions are needed. Further, clarification about the relationship between loneliness and stigma for this population is also warranted, as the effects of stigma on one's view of the self and others might be an additional treatment target. 
Running head: Review: Loneliness and substance dependence

Strengths of this review include the broad scope, inclusion of international samples and studies of all designs. Additionally, the review included unpublished theses. Limitations consist of our inclusion of studies with potential shortcomings in their methodologies, and variability in how loneliness and clinical correlates of loneliness were measured. In addition, our search strategy was refined to studies specifically examining loneliness, rather than including related concepts such as social isolation. It is possible that in doing so, our review may have failed to capture some aspects of the broader social context that are relevant for people with substance use problems. It is also possible that studies examining loneliness have been conducted in treatment service settings, yet the reports of these studies have not been made publicly available. As such, our systematic review is not immune to publication bias, as we were unable to access and include such potential studies due to our search strategy. Finally, rather than examining all dimensions of substance use, including people who use substances occasionally, we narrowed our review to include only people who experience substance use problems. While it is recognised that substance use occurs along a continuum, the rationale for this sample selection was due to the assumption that people with substance use problems are a distinct population from people who occasionally use substances. This is due to the increased stigma, increased mental health difficulties, and transitions in and out of active substance use that people with substance use problems may experience - all of which may enhance their propensity to experiencing loneliness.

\section{Conclusions}

Overall, this review of loneliness across substance dependent populations suggests that people with substance use problems are likely to feel lonelier than non-clinical comparator populations. Given the current literature, it is unclear what is most likely to contribute to loneliness for this population, and how best to alleviate loneliness and the associated bearing it has on physical and mental health. There is a lack of research that tests 
Running head: Review: Loneliness and substance dependence

components of theories of loneliness across this population. Future empirical research should focus on testing prominent loneliness theories (e.g. cognitive theory) across people with substance use problems in order to determine whether they predict loneliness and consequently can inform loneliness interventions. That just one study aimed to examine the effect of an intervention for loneliness across an alcohol-dependent population, suggests that this is an important gap in the literature. Guided by theoretical work, research exploring specific social variables and cognitions that might perpetuate loneliness and be the target of loneliness interventions is needed in this field.

Evidence for sound instruments to capture loneliness and effective interventions to alleviate loneliness for substance dependent populations was limited. At present, the UCLA measure of loneliness appears to be the most widely used. Advantages of using this tool are the potential for replicability and comparisons with other populations, as well as the potential of ruling out measurement variance in understanding research in this area. However, of note is that this tool has only been validated for a methadone maintenance sample and that it is an indirect approach to measurement, potentially posing challenges for face validity. Future research needs to focus on replicating validation studies that have already been conducted across this population, and/or qualitative work to determine the acceptability of current loneliness measures and potential necessity of developing tools that are more appropriate.

The majority of the studies reviewed did not utilise sound methodologies in that confounders were rarely adjusted for, and validated measures of loneliness for this specific population were rarely used. Future research should focus on employing longitudinal designs, with use of comparator groups and use of validated, multidimensional measures of loneliness. Furthering the theoretical understanding of loneliness and its related constructs will help to inform the development of targeted interventions, and ultimately overcome loneliness for this vulnerable population. 
Running head: Review: Loneliness and substance dependence

\section{Acknowledgements}

This research has been conducted with the support of the Australian Government Research Training Program Scholarship. This research did not receive any specific grant from funding agencies in the public, commercial, or not-for-profit sectors. All authors have contributed to the article preparation and have approved the final article.

\section{Conflict of interest}

The authors have no conflicts of interest to declare. 
Running head: Review: Loneliness and substance dependence

\section{References}

1. Cacioppo JT, Cacioppo S. The growing problem of loneliness. Lancet 2018;391:426.

2. Holt-Lunstad J. The potential public health relevance of social isolation and loneliness: Prevalence, epidemiology, and risk factors. Public Policy Aging Rep 2017;27:127-30.

3. Holt-Lunstad J, Smith TB, Layton JB. Social relationships and mortality risk: A metaanalytic review. PLoS Med 2010;7:e1000316.

4. Holt-Lunstad J, Smith TB, Baker M, Harris T, Stephenson D. Loneliness and social isolation as risk factors for mortality: A meta-analytic review. Perspect Psychol Sci 2015;10:227-37.

5. Rico-Uribe LA, Caballero FF, Martín-María N, Cabello M, Ayuso-Mateos JL, Miret M. Association of loneliness with all-cause mortality: A meta-analysis. PLoS One 2018;13: e0190033.

6. Peplau LA, Perlman D. Loneliness: a sourcebook of current theory, research, and therapy. USA: Wiley Interscience; 1982.

7. Weiss RS. Loneliness: The experience of emotional and social isolation. Cambridge, MA, US: The MIT Press; 1973.

8. Hawkley LC. Loneliness and social embeddedness in old age. In: Pachana N, editor. Encyclopedia of Geropsychology. Singapore: Springer; 2015.

9. Böger A, Huxhold O. Age-related changes in emotional qualities of the social network from middle adulthood into old age: How do they relate to the experience of loneliness? Psychol Aging 2018;33:482-96.

10. Hawkins-Elder H, Milfont TL, Hammond MD, Sibley CG. Who are the lonely? A typology of loneliness in New Zealand. Aust N Z J Psychiatry 2018;52:357-64. 
Running head: Review: Loneliness and substance dependence

11. Lasgaard M, Friis K, Shevlin M. "Where are all the lonely people?” A populationbased study of high-risk groups across the life span. Soc Psychiatry Psychiatr Epidemiol $2016 ; 51: 1373-84$.

12. Landeiro F, Barrows P, Musson EN, Gray AM, Leal J. Reducing social isolation and loneliness in older people: a systematic review protocol. BMJ Open 2017;7:e013778.

13. Lim MH, Gleeson JFM, Alvarez-Jimenez M, Penn DL. Loneliness in psychosis: a systematic review. Soc Psychiatry Psychiatr Epidemiol 2018;53:221-38.

14. Mann F, Bone JK, Lloyd-Evans B, Frerichs J, Pinfold V, Ma R, et al. A life less lonely: the state of the art in interventions to reduce loneliness in people with mental health problems. Soc Psychiatry Psychiatr Epidemiol 2017;52:627-38.

15. Crisp A, Gelder M, Goddard E, Meltzer H. Stigmatization of people with mental illnesses: a follow-up study within the Changing Minds campaign of the Royal College of Psychiatrists. World Psychiatry 2005;4:106-13.

16. Room R, Rehm J, Trotter RT, Paglia A, UÜstün TB. Cross-cultural views on stigma valuation parity and societal attitudes towards disability. In: Rehm J, editor. Disability and culture: Universalism and diversity. Seattle, WA: Hofgrebe \& Huber; 2001. p. 247-91.

17. Lichtenstein B, Laska MK, Clair JM. Chronic sorrow in the HIV-positive patient: Issues of race, gender, and social support. AIDS Patient Care STDs 2002;16:27-38.

18. Ware NC, Wyatt MA, Tugenberg T. Social relationships, stigma and adherence to antiretroviral therapy for HIV/AIDS. AIDS Care 2006;18:904-10.

19. Linz SJ, Sturm BA. The phenomenon of social isolation in the severely mentally ill. Perspect Psychiatr Care 2013;49:243-54.

20. Petersen J, Kaye J, Jacobs PG, Quinones A, Dodge H, Arnold A, et al. Longitudinal relationship between loneliness and social isolation in older adults: Results from the Cardiovascular Health Study. J Aging Health 2016;28:775-95. 
Running head: Review: Loneliness and substance dependence

21. Best D, Gow J, Taylor A, Knox A, White W. Recovery from heroin or alcohol dependence: A qualitative account of the recovery experience in Glasgow. J Drug Issues 2011;41:359-77.

22. Ingram I, Kelly PJ, Deane FP, Baker AL, Raftery DK. Loneliness in treatmentseeking substance-dependent populations: Validation of the Social and Emotional Loneliness Scale for Adults-Short Version. J Dual Diagn 2018;14:211-9.

23. Luhmann M, Hawkley LC. Age differences in loneliness from late adolescence to oldest old age. Devl Psychol 2016;52:943.

24. Baker D. All the lonely people: loneliness in Australia, 2001-2009. Canberra: The Australia Institute; 2012.

25. Leigh-Hunt N, Bagguley D, Bash K, Turner V, Turnbull S, Valtorta N, et al. An overview of systematic reviews on the public health consequences of social isolation and loneliness. Public Health 2017;152:157-71.

26. Hawkley LC, Cacioppo JT. Loneliness matters: a theoretical and empirical review of consequences and mechanisms. Ann Behav Med 2010;40:218-27.

27. Australian Psychology Society. Australian Loneliness Report: A survey exploring the loneliness levels of Australians and the impact on their health and wellbeing Melbourne, Australia: The Australian Psychological Society Ltd; 2018.

28. Cohen-Mansfield J, Hazan H, Lerman Y, Shalom V. Correlates and predictors of loneliness in older-adults: a review of quantitative results informed by qualitative insights. Int Psychogeriatr 2016;28:557-76.

29. Anderson CA. Attributional style, depression, and loneliness: A cross-cultural comparison of american and chinese students. Pers Soc Psychol Bull 1999;25:482-99. 30. Solano CH. Loneliness and perceptions of control: General traits versus specific attributions. J Soc Behav Pers 1987;2:201. 
Running head: Review: Loneliness and substance dependence

31. Vanhalst J, Soenens B, Luyckx K, Van Petegem S, Weeks MS, Asher SR. Why do the lonely stay lonely? Chronically lonely adolescents' attributions and emotions in situations of social inclusion and exclusion. J Pers Soc Psychol. 2015;109:932-48.

32. Akerlind I, Hörnquist JO. Stability and change in feelings of loneliness: a two-year prospective longitudinal study of advanced alcohol abuse. Scand J Psychol 1989;30:102-12.

33. Johnson RA. Loneliness among hospitalized alcohol abusers: Exploration and treatment. US: ProQuest Information \& Learning; 1985.

34. Valtorta NK, Kanaan M, Gilbody S, Hanratty B. Loneliness, social isolation and social relationships: what are we measuring? A novel framework for classifying and comparing tools. BMJ Open 2016;6:e010799.

35. Russell D, Peplau LA, Ferguson ML. Developing a measure of loneliness. J Pers Assess 1978;42:290-4.

36. Penning MJ, Liu G, Chou PHB. Measuring loneliness among middle-aged and older adults: The UCLA and de Jong Gierveld Loneliness Scales. Social Indicators Research 2014;118:1147-66.

37. Masi CM, Chen HY, Hawkley LC, Cacioppo JT. A meta-analysis of interventions to reduce loneliness. Pers Soc Psychol Rev 2011;15:219-66.

38. Moher D, Liberati A, Tetzlaff J, Altman DG. Preferred Reporting Items for Systematic Reviews and Meta-Analyses: The PRISMA Statement. PLoS Med 2009;6:e1000097.

39. National Heart Lung and Blood Institute NIH. Study Quality Assessment Tools: U.S. Department of Health and Human Services; 2019 [Available from: https://www.nhlbi.nih.gov/health-topics/study-quality-assessment-tools. 
Running head: Review: Loneliness and substance dependence

40. Viswanathana M, Patnodeb CD, Berkmana ND, Bassc EB, Changd S, Hartlinge L, et al. Recommendations for assessing the risk of bias in systematic reviews of health-care interventions. J Clin Epidemiol 2018;97:26-34.

41. Wang Z, Taylor K, Allman-Farinelli M, Armstrong B, Askie L, Ghersi D, et al. A systematic review: Tools for assessing methodological quality of human observational studies. NHMRC; 2019.

42. Critical Appraisal Skills Programme. CASP Qualitative Checklist 2018 [Available from: https://casp-uk.net/casp-tools-checklists/.

43. Jackson D, Turney R. Power analysis for random-effects meta-analysis. Res Syn Meth 2017;8:290-302.

44. van Assen MALM, van Aert RCM, Wicherts JM. Meta-Analysis Using Effect Size Distributions of Only Statistically Significant Studies. Psychol Methods 2014;20:293-309. 45. Akerlind I, Hörnquist JO, Bjurulf P. Prognosis in alcoholic rehabilitation: the relative significance of social, psychological, and medical factors. Int J Addict 1988;23:1171-95.

46. Akerlind I, Hörnquist JO, Hansson B. Loneliness correlates in advanced alcohol abusers. I. Social factors and needs. Scand J Soc Med. 1987;15:175-83.

47. Allen HA, Peterson JS, Whipple S. Loneliness and alcoholism: a study of three groups of male alcoholics. Int J Addict 1981;16:1255-8.

48. Armstrong JB. Loneliness and perceived stigmatization among older adults enrolled in opiate substitution treatment programs and the utilization of mental health services. US: ProQuest Information \& Learning; 2016.

49. Boyles BR. How does Alcoholics Anonymous affect drinking outcomes? A grounded theory perspective. US: ProQuest Information \& Learning; 2018.

50. Britton PC, Conner KR. Reliability of the UCLA Loneliness Scale in opiate dependent individuals. J Pers Assess 2007;88:368-71. 
Running head: Review: Loneliness and substance dependence

51. Russell DW. UCLA Loneliness Scale (Version 3): Reliability, validity, and factor structure. J Pers Assess 1996;66:20-40.

52. Cao Q, Liang Y. Perceived social support and life satisfaction in drug addicts: Selfesteem and loneliness as mediators. J Health Psychol 2017 [Epub ahead of print].

53. Conner KR, Britton PC, Sworts LM, Joiner Jr TE. Suicide attempts among individuals with opiate dependence: The critical role of belonging. Addict Behav 2007;32:1395-404.

54. Elton HL, Hörnquist JO. Abusers of alcohol granted disability pension: Prospective longitudinal and multidisciplinary studies: Linkoping University; 1983.

55. Hörnquist JO, Elton HF. A prospective longitudinal study of abusers of alcohol granted disability pension. Scand J Soc Med 1983;11:91-6.

56. Essex EL, Petras D, Massat CR. Predictors of loneliness among court-involved and substance abusing mothers. Women Crim Justice 2007;17:63-74.

57. Evans TJ. Sober and alone: A phenomenological exploration of the loneliness experienced by recovering alcoholics. US: ProQuest Information \& Learning; 2010.

58. Funk PE. A descriptive analysis of selected intrapersonal characteristics of drug abusers. ProQuest Information \& Learning, US; 1973. Retrieved from http://ezproxy.uow.edu.au/login?url=http://search.ebscohost.com/login.aspx?direct=true\&db $=$ psyh\&AN=1976-00695-001\&site=ehost-live Available from EBSCOhost psyh database. Accessed 16 April 2018.

59. Harris KS. The developmental effects of alcoholism in the adolescent. US: ProQuest Information \& Learning; 1983.

60. Hörnquist JO, Akerlind I. Loneliness correlates in advanced alcohol abusers. II. Clinical and psychological factors. Scand J Soc Med, 1987;15:225-32.

61. Hörnquist JO, Hansson B, Akerlind I. The working capacity of the alcohol abuser. Prognostic multiple regression analyses. Scand J Soc Med 1988;16:27-33. 
Running head: Review: Loneliness and substance dependence

62. Hosseinbor M, Yassini Ardekani SM, Bakhshani S, Bakhshani S. Emotional and social loneliness in individuals with and without substance dependence disorder. Int J High Risk Behav Addict 2014;3:e22688-e.

63. Itzick M, Segal JN, Possick C. Relationships in the lives of Israeli women coping with drug addiction: An ecosystemic perspective. J Soc Pers Relat 2019;36:741-60.

64. Kuerbis A, Mereish EH, Hayes M, Davis CM, Sijing S, Morgenstern J, et al. Testing cross-sectional and prospective mediators of internalized heterosexism on heavy drinking, alcohol problems, and psychological distress among heavy drinking men who have sex with men. J Stud Alcohol Drugs 2017;78:113-23.

65. Kuerbis A, Padovano HT, Shao SJ, Houser J, Muench FJ, Morgenstern J. Comparing daily drivers of problem drinking among older and younger adults: An electronic daily diary study using smartphones. Drug Alcohol Depend 2018;183:240-6.

66. Li F, Xu Y-M, Zhu J-H, Lu J, Zhong B-L. Pain of methadone-maintained heroin addicts: lonelier individuals feel more intense pain. Oncotarget 2017;8:79948-52.

67. Li H-J, Zhong B-L, Xu Y-M, Zhu J-H, Lu J. Sleep in lonely heroin-dependent patients receiving methadone maintenance treatment: longer sleep latency, shorter sleep duration, lower sleep efficiency, and poorer sleep quality. Oncotarget 2017;8:89278-83.

68. Medora NP. Variables affecting loneliness among individuals undergoing treatment in alcohol rehabilitation centers. US: ProQuest Information \& Learning; 1983.

69. Medora NP, Woodward JC. Loneliness and alcoholism. Wellness Perspectives $1990 ; 6: 42$.

70. Medora NP, Woodward JC. Factors associated with loneliness among alcoholic in rehabilitation centers. J Soc Psychol 1991;131:769-79.

71. Michaels AW. The prevalence of loneliness in alcoholic versus non-alcoholic treatment populations. ProQuest Information \& Learning, US; 1982. Retrieved from http://ezproxy.uow.edu.au/login?url=http://search.ebscohost.com/login.aspx?direct=true\&db 
Running head: Review: Loneliness and substance dependence

$=$ psyh $\& A N=1983-51365-001 \&$ site=ehost-live Available from EBSCOhost psyh database.

72. Neale J, Tompkins CNE, Strang J. Qualitative exploration of relationships between peers in residential addiction treatment. Health Soc Care Community 2018;26:e39-e46.

73. Nerviano VJ, Gross WF. Loneliness and locus of control for alcoholic males: Validity against Murray need and Cattell trait dimensions. J Clin Psychol 1976;32:479-84.

74. Newton TF, De La Garza R, Kalechstein AD, Tziortzis D, Jacobsen CA. Theories of addiction: methamphetamine users' explanations for continuing drug use and relapse. Am J Addict 2009;18:294-300.

75. Perodeau GM, du Fort GG. Psychotropic drug use and the relation between social support, life events, and mental health in the elderly. J Appl Gerontol 2000;19:23-41.

76. Price RH, Curlee-Salisbury J. Patient-treatment interactions among alcoholics. J Stud Alcohol 1975;36:659-69.

77. Schmidt DR. An ethnographic process evaluation of a faith-based therapeutic community for chemically addicted men: Trinity Evangelical Divinity School; 2002.

78. Schonfeld L, Dupree LW, Rohrer GE. Age-specific differences between younger and older alcohol abusers. J Clin Geropsychol 1995;1:219-27.

79. Siddique F, Ahmad Mann A, Ali T. Influence of social factors on drug use behavior in Punjab, Pakistan. Pak J Nutr 2012;11:1099-100.

80. Van Hasselt VB, Null JA, Kempton T, Bukstein OG. Social skills and depression in adolescent substance abusers. Addict Behav 1993;18:9-18.

81. Yang YJ, Xu YM, Chen WC, Zhu JH, Lu J, Zhong BL. Loneliness and its impact on quality of life in Chinese heroin-dependent patients receiving methadone maintenance treatment. Oncotarget 2017;8:79803-8.

82. Yeh M-C. Loneliness, alcohol and marijuana use among male college students. US: ProQuest Information \& Learning; 2002. 
Running head: Review: Loneliness and substance dependence

83. Zhong B-L, Xu Y-M, Zhu J-H, Liu X-J. Non-suicidal self-injury in Chinese heroindependent patients receiving methadone maintenance treatment: Prevalence and associated factors. Drug Alcohol Depend 2018;189:161-5.

84. Lancaster K, Seear K, Ritter A. Monograph 26: Reducing stigma and discrimination for people experiencing problematic alcohol and other drug use. National Drug and Alcohol Research Centre Sydney: National Drug and Alcohol Research Centre; 2018.

85. Best D, Beckwith M, Haslam C, Haslam SA, Jetten J, Mawson E, et al. Overcoming alcohol and other drug addiction as a process of social identity transition: the social identity model of recovery (SIMOR). Addict Res Theory 2016;24:111-23.

86. Levin I, Stokes JP. An examination of the relation of individual difference variables to loneliness. J Pers 1986;54:717-33.

87. de Jong-Gierveld J. Developing and testing a model of loneliness. J Pers Soc Psychol 1987;53:119-28.

88. Perlman D, Peplau LA. Toward a Social Psychology of Loneliness. In: R. Gilmour, Duck S, editors. Personal Relationships: 3 Relationships in Disorder. London: Academic Press; 1981. p. 31-56.

89. Russell D, Peplau LA, Cutrona CE. The revised UCLA loneliness scale: Concurrent and discriminant validity evidence. J Pers Soc Psychol 1980;39:472-80.

90. Hughes ME, Waite LJ, Hawkley LC, Cacioppo JT. A short scale for measuring loneliness in large surveys: Results from two population-based studies. Res Aging 2004;26:655-72.

91. Ditommaso E, Brannen C, Best LA. Measurement and validity characteristics of the short version of the social and emotional loneliness scale for adults. Educat Psychol Meas 2004;64:99-119. 
Running head: Review: Loneliness and substance dependence

92. Jowker B. Psychometric properties of the short form of social and emotional loneliness scale for adults (SELSA-S). J Behav Sci 2012;5:311-7.

93. Bradley R. Measuring loneliness. Unpublished doctoral dissertation: Washington State University; 1969.

94. Belcher MJ. Loneliness: A review, theoretical framework, and its therapeutic implications. 1971.

95. Belcher MJ. The measurement of loneliness: A validation of the Belcher Extended Loneliness Scale (BELS). Dissertation Abstracts International: Illinois Institute of Technology; 1973.

96. Sisenwein RJ. Loneliness and the individual as viewed by himself and others. Unpublished doctoral dissertation: Columbia University, New York; 1964.

97. Elton M, Hörnquist JO. Grounds for disability pension: Younger abusers of alcohol as compared with older ones. Scand J Soc Med 1983;11:53-8.

98. Woodward JC. Loneliness and Solitude: Phenomena, Incidence and Factorial Relationships.: University of Nebraska-Lincoln; 1967 - Delete?.

99. Woodward J. The solitude of loneliness. Lexington, MA: Lexington Books; 1988.

100. Fillenbaum C, Dellinger D, Maddox G, Pfeiffer E. Assessment of individual functional status in a program evaluation and resource allocation model. In: Development CftSoAaH, editor. Multidimensional functional assessment: The OARS Methodology. Durham, NC: Duke University; 1978. p. 3-12.

101. Harel Z, Deimling GT. Social resources and mental health: An empirical refinement. J Gerontol 1984;39:747-52.

102. Marlatt GA, Gordon JR. Determinants of relapse: Implications for the maintenance of behavior change. In: Davidson PO, Davidson SM, editors. Behavioral medicine: Changing health lifestyles. New York: Brunner/Mazel; 1980. p. 1410-52. 
Running head: Review: Loneliness and substance dependence

103. Marlatt GA, Gordon JR. Relapse prevention: Maintenance strategies in the treatment of addictive behaviors. New York: Guilford Press; 1985.

104. Asher SR, Hymel S, Renshaw PD. Loneliness in Children. Child Dev 1984;55:145664.

105. Cicchetti DV. Guidelines, criteria, and rules of thumb for evaluating normed and standardized assessment instruments in psychology. Psychol Assess 1994;6:284.

106. Carstensen LL. Social and emotional patterns in adulthood: support for socioemotional selectivity theory. Psychol Aging 1992;7:331-8.

107. Cacioppo S, Grippo AJ, London S, Goossens L, Cacioppo JT. Loneliness: Clinical import and interventions. Perspect Psychol Sci 2015;10:238-49.

108. Cohen-Mansfield J, Perach R. Interventions for alleviating loneliness among older persons: a critical review. Am J Health Promot 2015;29:e109-e25.

109. Maes M, Klimstra T, Van den Noortgate W, Goossens L. Factor structure and measurement invariance of a multidimensional loneliness scale: Comparisons across gender and age. J Child Fam Stud 2014;24:1829-37.

110. Heinrich LM, Gullone E. The clinical significance of loneliness: A literature review. Clin Psychol Rev 2006;26:695-718.

111. de Jong Gierveld J, van Tilburg T, Dykstra P. Loneliness and social isolation: New ways of theorizing and conducting research. In: Vangelisti AL, Perlman D, editors. The Cambridge Handbook of Personal Relationships. 2 ed. Cambridge, England: Cambridge University Press; 2018. p. 391-404.

112. Shiovitz-Ezra S, Ayalon L. Use of direct versus indirect approaches to measure loneliness in later life. Res Aging. 2012;34:572-91. 
Running head: Review: Loneliness and substance dependence

113. Russell D. The Measurement of Loneliness. In Peplau L, Perlman D, editors.

Loneliness: A Sourcebook of Current Theory, Research and Therapy. United States: Wiley; 1982. p. 81-104.

114. Solano CH. Two measures of loneliness: A comparison. Psychol Rep 1980;46:23-8. 
Records identified through database searching $(n=3,003)$

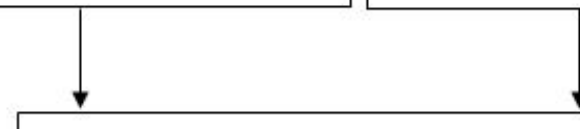

Records after duplicates removed $(n=1,628)$

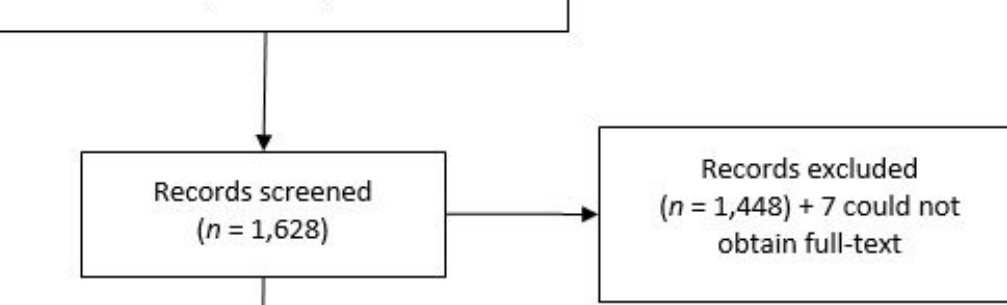

Studies included in qualitative synthesis $(n=41)$
Additional records identified through other sources (reference list screening) $(n=11)$
Full-text articles excluded, with reasons ( $n=132)$ :

- Incomplete study, $n=2$

- Not an empirical source, $n=5$

Not in English language, $n=25$

- Not a SUD population, $n=15$

- Loneliness not measured/not an outcome, $n=85$

Figure 1. PRISMA Flow diagram. SUD, substance use disorder. 
Table 1. Study characteristics

\begin{tabular}{|c|c|c|c|c|c|}
\hline Article & Objectives & $\begin{array}{c}\text { Sample size and } \\
\text { sociodemographic }\end{array}$ & Methods & Outcome & Quality rating \\
\hline $\begin{array}{l}\text { Akerlind, } \\
\text { Hornquist, } \\
\text { Bjurulf, } 1988 \text { [45] }\end{array}$ & $\begin{array}{l}\text { To determine the importance } \\
\text { of social, psychological, and } \\
\text { medical factors in prediction of } \\
\text { post-treatment functioning. } \\
\text { The outcome measure, } \\
\text { longitudinal working capacity, } \\
\text { was assumed to reflect overall } \\
\text { functional capacity. }\end{array}$ & $\begin{array}{l}\text { N: } 34 \\
\text { Response rate: Not } \\
\text { reported } \\
\text { Country: Sweden } \\
\text { Gender: Male } \\
\text { Age: } 24-60(M=41.5, \\
S D=10.5) \\
\text { Substance use: Alcohol }\end{array}$ & $\begin{array}{l}\text { Design: Longitudinal } \\
\text { Setting: Community/ Inpatient alcoholism } \\
\text { treatment service/ Sociomedical outpatient clinic/ } \\
\text { Psychiatric outpatient clinic/ Vocational } \\
\text { rehabilitation service. } \\
\text { Year: } 1978 \text { and } 1979 \\
\text { Procedure: The participants were classified into } \\
\text { three groups. The subjects followed the regular } \\
\text { treatment programs at the different settings and } \\
\text { completed the assessment measures. }\end{array}$ & $\begin{array}{l}\text { Loneliness appeared as the most important } \\
\text { factor for working capacity in the stepwise } \\
\text { multiple regression analysis of the data. } \\
\text { Rehabilitation of advanced alcoholics, normal } \\
\text { psychological mechanisms related to perceived } \\
\text { well- being and quality of life play an } \\
\text { important part. }\end{array}$ & Fair \\
\hline $\begin{array}{l}\text { Akerlind I, } \\
\text { Hornquist JO, } \\
\text { Hansson B, } 1987 \\
{[46]}\end{array}$ & $\begin{array}{l}\text { To determine whether } \\
\text { loneliness correlates with } \\
\text { quality of life (comprised of } \\
\text { six domains: structural, } \\
\text { material, social, activity, } \\
\text { psychological, physical). }\end{array}$ & $\begin{array}{l}\text { N: } 95 \text { (Group 1: } 54 \text { males, } \\
7 \text { females; Group 2: } 34 \\
\text { males) } \\
\text { Response rate: Not } \\
\text { reported } \\
\text { Country: Sweden } \\
\text { Gender: Males and } \\
\text { Females } \\
\text { Age: } 24-60 \text { (M=44.5, } \\
S D=10.2 \text { ) } \\
\text { Substance use: Alcohol }\end{array}$ & $\begin{array}{l}\text { Design: Longitudinal } \\
\text { Setting: Applicants for disability pension in } \\
\text { Ostergotland, Sweden } \\
\text { Year: 1978-1981 } \\
\text { Procedure: Participants were contacted and } \\
\text { examined on two occasions. Participants self-rated } \\
\text { their loneliness. Correlations between loneliness } \\
\text { scores and participant's social background (12 } \\
\text { parameters), external social network ( } 20 \\
\text { parameters), work and activities ( } 27 \text { parameters), } \\
\text { societal position (9 parameters), life priorities (29 } \\
\text { parameters) and life satisfaction ( } 25 \text { parameters) } \\
\text { were calculated. }\end{array}$ & $\begin{array}{l}\text { No results presented or comment made about } \\
\text { whether loneliness changes over time. } \\
\text { Quantitative aspects of social network was not } \\
\text { found to be related to loneliness. } \\
\text { Dissatisfaction with quality of relationships } \\
\text { found to relate to loneliness. } \\
\text { - Loneliness related to quality of life. } \\
\text { Age was negatively related to loneliness; } \\
\text { Females were lonelier; Income, education \& } \\
\text { occupation were not related to loneliness; } \\
\text { Residence in an urban area was related to } \\
\text { loneliness; Difficulties in the current } \\
\text { administration of one's economy were related } \\
\text { to loneliness; insecurity and inferiority was } \\
\text { related to loneliness. }\end{array}$ & Poor \\
\hline $\begin{array}{l}\text { Akerlind I, } \\
\text { Hornquist JO, } \\
1989 \text { [32] }\end{array}$ & $\begin{array}{l}\text { To analyse covariations } \\
\text { between longitudinal changes } \\
\text { in loneliness and changes in } \\
\text { social network, psychological } \\
\text { wellbeing, life satisfaction, } \\
\text { activities, adaption to work } \\
\text { and non-work situation, }\end{array}$ & $\begin{array}{l}\text { N: } 95 \text { ( } 88 \text { males, } 7 \\
\text { females) } \\
\text { Response rate: Not } \\
\text { reported }\end{array}$ & $\begin{array}{l}\text { Design: Cross-sectional and Longitudinal } \\
\text { Setting: Community/inpatient alcoholism } \\
\text { treatment service, sociomedical outpatient clinic, } \\
\text { psychiatric outpatient clinic, vocational } \\
\text { rehabilitation service. }\end{array}$ & $\begin{array}{l}\text { Cross-sectional: Loneliness correlated with } \\
\text { wellbeing, life satisfaction, psychiatry (anxiety, } \\
\text { autonomic disturbance, muscular tension, } \\
\text { reduced sleep, passivity, global rating of } \\
\text { illness), activity (sports and recreation, } \\
\text { shopping), adaptation (meaningfully occupied } \\
\text { in free time), social network (number and } \\
\text { availability of friends and acquaintances) and }\end{array}$ & Fair \\
\hline
\end{tabular}




\begin{tabular}{|c|c|c|c|c|c|}
\hline & $\begin{array}{l}\text { psychiatric symptoms, and } \\
\text { alcohol consumption. }\end{array}$ & $\begin{array}{l}\text { Country: Sweden } \\
\text { Gender: Males and } \\
\text { Females } \\
\text { Age: } 24-60 \text { years } \\
(M=44.5, S D=10.2) \\
\text { Substance use: Alcohol }\end{array}$ & $\begin{array}{l}\text { Year: } 1978 \text { and } 1979 \\
\text { Procedure: Participants were examined on two } \\
\text { occasions initially and re-examined after two } \\
\text { years. Participant's self-rated loneliness. Other } \\
\text { variables assessed via structured interview by a } \\
\text { social worker and a semi-structured interview } \\
\text { conducted by a psychiatrist. }\end{array}$ & $\begin{array}{l}\text { alcohol consumption at second assessment } \\
\text { only. } \\
\text { Longitudinal: Change in loneliness over two } \\
\text { years was accompanied by changes in } \\
\text { wellbeing (indolence, inferiority, perceived } \\
\text { negative treatment from others), psychiatry } \\
\text { (sadness, inability to feel, pessimistic thoughts, } \\
\text { suicidal thoughts, autonomic disturbance), life } \\
\text { satisfaction, activity (time spent in sports and } \\
\text { rec, resting and relaxation), adaptation } \\
\text { (meaningfully occupied in free time] social } \\
\text { network (availability of friends and } \\
\text { acquaintances, availability of close friends). } \\
\text { Loneliness related to perceived quality and } \\
\text { satisfaction with relationships, not to quantity } \\
\text { of relationships. } \\
\text { Loneliness not longitudinally related to alcohol } \\
\text { consumption. } \\
\text { Psychological wellbeing (particularly } \\
\text { indolence and self-evaluation in relation to } \\
\text { others) most salient correlate with loneliness } \\
\text { and changes to loneliness. } \\
\text { At both examinations a great minority of } \\
\text { individuals (45-35\%) scored at the upper half } \\
\text { of the scale, indicating salient feelings of } \\
\text { loneliness. }\end{array}$ & \\
\hline 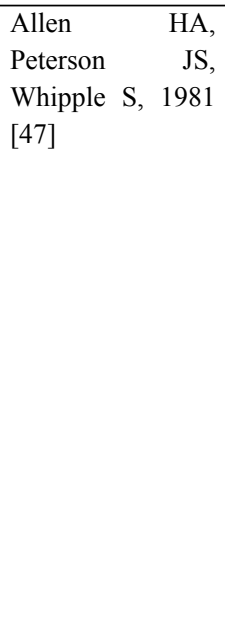 & $\begin{array}{l}\text { To investigate the relationship } \\
\text { between alcoholism and } \\
\text { loneliness at various stages of } \\
\text { recovery. It was hypothesised } \\
\text { that people who use alcohol in } \\
\text { the acute group would be } \\
\text { lonelier than those in the } \\
\text { chronic group, who would in } \\
\text { turn be lonelier than the } \\
\text { recovering group. }\end{array}$ & $\begin{array}{l}\text { N: } 45 \text { (all males) } \\
\text { Response rate: Not } \\
\text { reported } \\
\text { Country: America } \\
\text { Gender: Male } \\
\text { Age: Acute Group } \\
\text { (detoxification) } M=45.1 \text {; } \\
\text { Chronic Group (outpatient } \\
\text { treatment) } M=32.3 ; \\
\text { Recovering Group } \\
\text { (members of AA) } M=41 \\
\text { Substance use: Alcohol }\end{array}$ & $\begin{array}{l}\text { Design: Cross-sectional } \\
\text { Setting: Outpatient mental health treatment } \\
\text { service. } \\
\text { Year: Not reported } \\
\text { Procedure: Participants were volunteers who had } \\
\text { had contact with the mental health centre. The } \\
\text { loneliness scale was given within } 3 \text { days of entry } \\
\text { to the program. }\end{array}$ & $\begin{array}{l}\text { Differences exist within this population, with } \\
\text { those currently drinking (acute group) most } \\
\text { lonely, those with } 1 \text { year's sobriety (members } \\
\text { of AA) the least lonely, and those in treatment } \\
\text { (chronic group) falling in the middle. }\end{array}$ & Poor \\
\hline
\end{tabular}




\begin{tabular}{|c|c|c|c|c|c|}
\hline $\begin{array}{l}\text { Armstrong JB, } \\
2016[48]\end{array}$ & $\begin{array}{l}\text { To examine the role that } \\
\text { loneliness and perceived } \\
\text { stigmatisation play in the } \\
\text { decision to seek mental health } \\
\text { services among older adults } \\
\text { enrolled in opiate substitution } \\
\text { treatment. }\end{array}$ & $\begin{array}{l}\text { N: } 94 \\
\text { Response rate: } 98 \% \\
\text { Country: America } \\
\text { Gender: Not reported } \\
\text { Age: } 50-71 \quad(M=57.22, \\
S D=5.13) \\
\text { Substance use: Opioids }\end{array}$ & $\begin{array}{l}\text { Design: Cross-sectional } \\
\text { Setting: Outpatient substance dependence } \\
\text { treatment service } \\
\text { Year: Not reported } \\
\text { Procedure: Participants were actively enrolled in } \\
\text { the opiate substitution treatment program at the } \\
\text { service. Opportunity to volunteer to participate } \\
\text { was offered by their regular chemical dependency } \\
\text { counsellors. Clients were offered a } \$ 3 \\
\text { McDonald's gift card as an incentive. The } \\
\text { counsellors administered the surveys at the } \\
\text { beginning of the monthly session. }\end{array}$ & $\begin{array}{l}\text { Participants who reported utilising more } \\
\text { available mental health services also tended to } \\
\text { indicate higher degrees of both loneliness and } \\
\text { perceived stigmatisation. }\end{array}$ & Fair \\
\hline $\begin{array}{l}\text { Boyles BR, } 2018 \\
{[49]}\end{array}$ & $\begin{array}{l}\text { Study One: To inform an emic } \\
\text { understanding of change } \\
\text { processes embedded in AA's } \\
\text { literature that may explain } \\
\text { continuous abstinence } \\
\text { experienced by community } \\
\text { AA members. } \\
\text { Study Two: To identify AA } \\
\text { change processes and their } \\
\text { functioning within AA's } \\
\text { fellowship in order to inform a } \\
\text { guiding theory that details how } \\
\text { continuous abstinence occurs } \\
\text { for AA members. }\end{array}$ & $\begin{array}{l}\text { N: Study One: } N=3 \text { (3 } \\
\text { males); Study Two: } N=5 \\
\text { (4 males, } 1 \text { female) } \\
\text { Response rate: Study } \\
\text { One: } 33 \% \text { ( } 9 \text { invited to } \\
\text { participate, of the } 7 \text { that } \\
\text { accepted, } 2 \text { withdrew, } 1 \\
\text { did not submit data, } 1 \\
\text { non-adherent); Study Two: } \\
\text { 50\% (10 invited, } 7 \\
\text { accepted, } 2 \text { of these } \\
\text { withdrew) } \\
\text { Country: America } \\
\text { Gender: Male and female } \\
\text { Age: Study One: } 30-59 \\
\text { years; Study Two: } 48-69 \\
\text { years } \\
\text { Substance use: Alcohol } \\
\text { and opioids }\end{array}$ & $\begin{array}{l}\text { Design: Cross-sectional, qualitative } \\
\text { Setting: Members of AA } \\
\text { Year: } 2016 \\
\text { Procedure: Study One: This study uses } \\
\text { qualitative content analysis of the AA literature } \\
\text { and a grounded theory approach to AA's } \\
\text { fellowship. Study Two: The qualitative data were } \\
\text { collected through focus groups to inform an } \\
\text { understanding of how change occurs within AA. } \\
\text { Six focus groups were conducted 1-2 weeks apart. }\end{array}$ & $\begin{array}{l}\text { Study One: } \\
\text { - Only one of the passages identified by the } \\
\text { content analysis suggests a change in } \\
\text { loneliness (e.g. "we can be alone at perfect } \\
\text { peace and ease", p. } 75 \text { ). } \\
\text { A keyword search of the AA text indicates } \\
\text { loneliness is discussed at least } 12 \text { times. } \\
\text { Study Two: } \\
\text { - Grounded theory analysis of focus group data } \\
\text { suggests that AA involvement produced } \\
\text { changes in insecurity, loneliness (marked by a } \\
\text { sense of belonging), life meaning, anxiety and } \\
\text { shame. } \\
\text { An early stage of the AA experience, reported } \\
\text { by the participants, included a reduction in } \\
\text { loneliness. } \\
\text { In middle stage of AA, the participants } \\
\text { reported becoming aware of an internal or } \\
\text { intrapersonal loneliness. } \\
\text { The focus group participants indicated } \\
\text { problems with loneliness were not fully } \\
\text { resolved until late AA. }\end{array}$ & Good \\
\hline $\begin{array}{l}\text { Britton PC, } \\
\text { Conner KR, } 2007\end{array}$ & $\begin{array}{l}\text { To examine the internal } \\
\text { consistency and test-retest }\end{array}$ & N: 121 (61 females, 60 & Design: Longitudinal & $\begin{array}{l}\text { The internal consistency }(0.87) \text { and test-retest } \\
\text { reliability }(r=0.77) \text { of the UCLA-LS in a }\end{array}$ & Fair \\
\hline
\end{tabular}




\begin{tabular}{|c|c|c|c|c|c|}
\hline [50] & $\begin{array}{l}\text { reliability of the self-report } \\
\text { UCLA-LS (Russell } 1996 \text { [51]) } \\
\text { in methadone maintenance } \\
\text { patients at an urban university } \\
\text { hospital. }\end{array}$ & $\begin{array}{l}\text { males) } \\
\text { Response rate: } 96 \% \\
\text { baseline }(n=117) ; 57 \% \\
\text { follow-up ( }(n=67) \\
\text { Country: America } \\
\text { Gender: Male and female } \\
\text { Age: } 21-59 \text { years } \\
(M=41.9, S D=9.7) \\
\text { Substance use: Opioids }\end{array}$ & $\begin{array}{l}\text { Setting: Outpatient substance dependence } \\
\text { treatment service } \\
\text { Year: } 2005 \\
\text { Procedure: Participants recruited through poster } \\
\text { advertisements at methadone clinic. Interviewer } \\
\text { met with participants for } 1 \text { hour to complete } \\
\text { battery of self-report and interviewer-based } \\
\text { instruments. Participants invited to return after } 14 \\
\text { days for a follow-up session. Participants paid a } \\
\$ 30 \text { grocery gift card following each assessment. }\end{array}$ & $\begin{array}{l}\text { clinical sample of individuals with opiate } \\
\text { dependence in MMT were comparable to those } \\
\text { obtained from the UCLA-LS in other samples } \\
\text { (Russell } 1996 \text { [51]). } \\
\text { No differences in mean loneliness scores (i.e. } \\
\text { male vs. female, African American vs. White, } \\
\text { levels of education). } \\
\text { No differences in loneliness scores from first to } \\
\text { second administration of the UCLA-LS. }\end{array}$ & \\
\hline $\begin{array}{l}\text { Cao Q, Liang Y, } \\
2017 \text { [52] }\end{array}$ & $\begin{array}{l}\text { To test the mediating effect of } \\
\text { self-esteem and loneliness on } \\
\text { the relationship between social } \\
\text { support and life satisfaction in } \\
\text { people who use drugs, and to } \\
\text { investigate the contribution of } \\
\text { each specific mediator } \\
\text { variable. }\end{array}$ & $\begin{array}{l}\text { N: } 110 \text { (91 males, } 19 \\
\text { females) } \\
\text { Response rate: } 84.6 \% \\
\text { (110 of } 130 \text { distributed) } \\
\text { Country: China } \\
\text { Gender: Male and female } \\
\text { Age: } 18-54 \text { years } \\
(M=38.47, S D=7.31) \\
\text { Substance use: Heroin: } \\
80.7 \%(n=88) ; \\
\text { Methamphetamine: } 8.2 \% \\
(n=9) ; \text { Cocaine: } 4.5 \%(n \\
=5) \text {; Marijuana: } 3.3 \%(n \\
=4) \text {; Other: } 3.3 \%(n=4)\end{array}$ & $\begin{array}{l}\text { Design: Cross-sectional } \\
\text { Setting: Guangdong Fangcun Brain Hospital in } \\
\text { China. } \\
\text { Year: Not reported } \\
\text { Procedure: Participants completed the } \\
\text { questionnaires in a waiting room of the hospital. } \\
\text { Instruments took approximately } 30 \text { minutes to } \\
\text { complete. Confirmatory Factor analysis } \\
\text { conducted. }\end{array}$ & 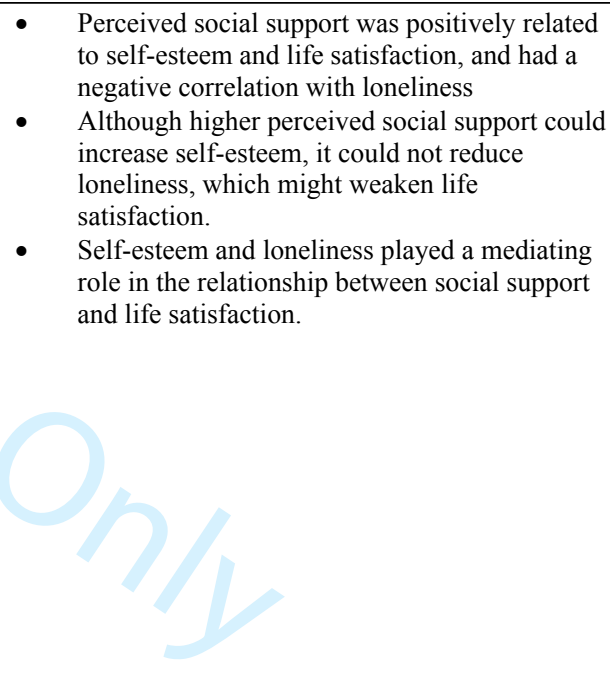 & Fair \\
\hline $\begin{array}{l}\text { Conner KR, } \\
\text { Britton PC, } \\
\text { Sworts LM, } \\
\text { Joiner TE, } 2007 \\
\text { [53] }\end{array}$ & $\begin{array}{l}\text { To determine if low belonging, } \\
\text { high burdensomeness, and } \\
\text { high loneliness are associated } \\
\text { with attempted suicide among } \\
\text { individuals with opiate } \\
\text { dependence. } \\
\text { To explore whether or not }\end{array}$ & $\begin{array}{l}\text { N: } 131 \text { (69 females, } 62 \\
\text { males) } \\
\text { Response rate: Not } \\
\text { reported } \\
\text { Country: America }\end{array}$ & $\begin{array}{l}\text { Design: Cross-sectional } \\
\text { Setting: Outpatient substance dependence } \\
\text { treatment service } \\
\text { Year: } 2005 \\
\text { Procedure: Participants recruited through poster }\end{array}$ & $\begin{array}{l}\text { Moderate difference in loneliness between } \\
\text { suicide attempters and non-attempters. } \\
\text { Higher scores on loneliness scale were } \\
\text { associated with a higher probability of an } \\
\text { attempt. However, after adjusting for } \\
\text { covariates, higher scores on loneliness were } \\
\text { not statistically associated with a higher } \\
\text { probability of an attempt. } \\
\text { - Small differences in loneliness between }\end{array}$ & Fair \\
\hline
\end{tabular}




\begin{tabular}{|c|c|c|c|c|c|}
\hline & $\begin{array}{l}\text { unintentional overdose is also } \\
\text { associated with perceived } \\
\text { belonging, burdensomeness, } \\
\text { and loneliness. }\end{array}$ & $\begin{array}{l}\text { Gender: Male and female } \\
\text { Age: } 21-59 \text { years } \\
(M=41.8, S D=9.6) \\
\text { Substance use: Opioids }\end{array}$ & $\begin{array}{l}\text { advertisements at methadone clinic. Interviewer } \\
\text { met with participants for } 1 \text { hour to complete } \\
\text { battery of self-report and interviewer-based } \\
\text { instruments. Participants invited to return after } 14 \\
\text { days for a follow-up session. Participants paid a } \\
\text { \$3 gift card following each assessment. }\end{array}$ & $\begin{array}{l}\text { overdose and non-overdose subjects. } \\
\text { With the exception of the unadjusted analysis, } \\
\text { the results did not support an association of } \\
\text { loneliness and suicidal behaviour. }\end{array}$ & \\
\hline $\begin{array}{l}\text { Elton HL, } \\
\text { Hornquist JO, } \\
1983 \text { [54] }\end{array}$ & $\begin{array}{l}\text { Aimed to compare alcohol } \\
\text { users with non-users on } \\
\text { variables (such as loneliness) } \\
\text { prior to and after receiving } \\
\text { their disability pension. These } \\
\text { groups were also compared to } \\
\text { a group of users (in } \\
\text { rehabilitation) who were not } \\
\text { receiving a pension. } \\
\text { *NB. Thesis contained } 6 \\
\text { studies - all with same sample } \\
\text { - only studies 2, 3, and } 6 \text { of } \\
\text { this thesis were included in the } \\
\text { review. } \\
\text { Study } 5 \text { was included in the } \\
\text { review as a separate published } \\
\text { journal article (Hornquist \& } \\
\text { Elton, } 1983 \text { [55]) } \\
\text { Studies } 1 \text { and } 4 \text { did not meet } \\
\text { inclusion criteria for the } \\
\text { review. }\end{array}$ & $\begin{array}{l}\text { N: } 78 \text { (pensioned users; } \\
54 \text { males, } 7 \text { females) } \\
\text { Matched reference } \\
\text { groups: } 27 \text { (pensioned } \\
\text { non-users); } 30 \text { (non- } \\
\text { pensioned users } \\
\text { undergoing rehabilitation) } \\
\text { Response rate: } 82 \% \\
(n=61) \text { at baseline; } 92 \% \\
(n=56) \text { at } 2 \text {-years (Study } 6 \\
\text { only) } \\
\text { Country: Sweden } \\
\text { Gender: Male and female } \\
\text { Age: } M=46 \text { years } \\
\text { Substance use: Alcohol }\end{array}$ & $\begin{array}{l}\text { Design: Cross-sectional and longitudinal } \\
\text { Setting: People who use alcohol in the } \\
\text { community accessing disability pension; and a } \\
\text { matched sample of people who use alcohol } \\
\text { accessing rehabilitation (inpatient or outpatient } \\
\text { unknown) } \\
\text { Year: } 1 \text { January 1978-1 July } 1979 \\
\text { Procedure: } \\
\text { Study 2: Cross-sectional interviews. } \\
\text { Study 3: Cross-sectional interviews same as Study } \\
\text { 2. Sample divided into older and younger } \\
\text { subgroups to make comparisons. } \\
\text { Study 6: Longitudinal. Interviews conducted prior } \\
\text { to receiving a pension and again after two-years. }\end{array}$ & $\begin{array}{l}\text { - Study 2: Mean loneliness scores were found to } \\
\text { be different amongst pensioned people who } \\
\text { use alcohol compared to the matched reference } \\
\text { groups (pensioned people who do not use } \\
\text { alcohol / non-pensioned rehabilitators). } \\
\text { Pensioned group was found to have higher } \\
\text { levels of loneliness compared to the matched } \\
\text { samples. } \\
\text { Study 3: Younger people who use alcohol } \\
\text { found to be lonelier than older people who use } \\
\text { alcohol. } \\
\text { Study 6: Loneliness amongst pensioned people } \\
\text { who use alcohol contributed to changes (from } \\
\text { baseline to two-year follow-up) to wellbeing, } \\
\text { psychiatric status, need satisfaction, } \\
\text { intellectual performance, and alcohol } \\
\text { consumption. }\end{array}$ & $\begin{array}{l}\text { Study 2: Poor } \\
\text { Study 3: Poor } \\
\text { Study 6: Fair }\end{array}$ \\
\hline
\end{tabular}




\begin{tabular}{|c|c|c|c|c|c|}
\hline $\begin{array}{l}\text { Essex EL, Petras, } \\
\text { D, Massat CR, } \\
2007 \text { [56] }\end{array}$ & $\begin{array}{l}\text { To determine what predicts } \\
\text { loneliness for substance using, } \\
\text { court-involved mothers. }\end{array}$ & $\begin{array}{l}\text { N: } 94 \text { (all females) } \\
\text { Response rate: } 94 \% \\
\text { Country: America } \\
\text { Gender: Female } \\
\text { Age: } 19-50(M=35.4 \\
S D=6.3) \\
\text { Substance use: Heroin } \\
(66 \%) \\
\text { Cocaine }(22 \%) \\
\text { Other (12\%) }\end{array}$ & $\begin{array}{l}\text { Design: Cross-sectional } \\
\text { Setting: Adults who were substance involved and } \\
\text { convicted of a criminal offense and ordered to } \\
\text { TASC. } \\
\text { Year: Pooled samples from } 2000 \text { and 2004-2005 } \\
\text { Procedure: Potential subjects were referred to the } \\
\text { researchers by the Chicago metropolitan area } \\
\text { offices of TASC. Flyers and letters describing the } \\
\text { study were distributed to women who met } \\
\text { eligibility criteria. Subjects completed } 1.5 \text {-hour } \\
\text { structured interviews. Data was pooled from two } \\
\text { cross-sectional exploratory studies. }\end{array}$ & $\begin{array}{l}\text { - Found support for viewing loneliness in this } \\
\text { population as stemming from: } \\
\text { (i) Characteristics of the women themselves } \\
\text { (the presence or absence of co-occurring } \\
\text { conditions); } \\
\text { (ii) Child characteristics (number of minors in } \\
\text { the home); } \\
\text { (iii) Partner relations (degree of domestic } \\
\text { violence experienced in their relations with } \\
\text { partners); and } \\
\text { (iv) Informal and formal social supports. } \\
\text { Mothers' satisfaction with substance use } \\
\text { services was found to be a negative predictor } \\
\text { of loneliness. } \\
\text { Level of informal social support had strongest } \\
\text { relationship to loneliness. }\end{array}$ & Fair \\
\hline $\begin{array}{l}\text { Evans TJ, } 2010 \\
{[57]}\end{array}$ & $\begin{array}{l}\text { To understand loneliness, as } \\
\text { experienced by recovering } \\
\text { alcoholics. } \\
\text { To explore what factors } \\
\text { recovering alcoholics } \\
\text { identified as contributing to } \\
\text { their experience of loneliness. }\end{array}$ & $\begin{array}{l}\text { N: } 8 \text { (5 males, } 3 \text { females) } \\
\text { Response rate: N/A } \\
\text { Country: America } \\
\text { Gender: Male and female } \\
\text { Age: Not reported } \\
\text { Substance use: Alcohol }\end{array}$ & $\begin{array}{l}\text { Design: Cross-sectional/ Qualitative } \\
\text { Setting: AA meetings } \\
\text { Year: } 2009 \\
\text { Procedure: Participants were recruited from local } \\
\text { AA meetings. Potential participants were asked to } \\
\text { take a short self-report survey. Face to face in- } \\
\text { depth interviews then completed and lasted 1.5-2 } \\
\text { hours each. Interviews were tape recorded and } \\
\text { transcribed verbatim. }\end{array}$ & $\begin{array}{l}\text { Loneliness described to include feelings of: } \\
\text { fearful, empty, hopeless, overwhelmed, } \\
\text { misunderstood, suicidal, isolated from others, } \\
\text { and alone in a crowd. } \\
\text { Participants attributed their experience with } \\
\text { loneliness during recovery to a variety of } \\
\text { factors, including severed or strained } \\
\text { relationships, the inability to trust, a history of } \\
\text { insecure or inept parental attachment, and the } \\
\text { re-occurrence of negative thoughts. }\end{array}$ & Good \\
\hline $\begin{array}{l}\text { Funk PE, } 1973 \\
{[58]}\end{array}$ & $\begin{array}{l}\text { To describe six intrapersonal } \\
\text { characteristics and their } \\
\text { possible relationship to drug } \\
\text { use. The six intrapersonal } \\
\text { characteristics were: anxiety, } \\
\text { loneliness, affection, guilt, } \\
\text { punishment and frustration. }\end{array}$ & $\begin{array}{l}\text { N: } 35 \text { ( } 23 \text { females, } 12 \\
\text { males) } \\
\text { Response rate: } 81 \%(8 \\
\text { removed by researchers) } \\
\text { Country: America } \\
\text { Gender: Male and female } \\
\text { Age: } 15-55 \text { years }\end{array}$ & $\begin{array}{l}\text { Design: Cross-sectional/qualitative } \\
\text { Setting: Volunteer who used drugs residing in the } \\
\text { community } \\
\text { Year: Not reported } \\
\text { Procedure: Participants were invited to the study } \\
\text { through counsellors at the Gallatin County Help } \\
\text { Centre, teachers, and friends, as well as } \\
\text { newspaper classified ads. Data collected via audio } \\
\text { tapes and client self-perceptions. Clients }\end{array}$ & $\begin{array}{l}\text { Loneliness, anxiety, affection, frustration, } \\
\text { punishment, and guilt were found to be present } \\
\text { in some form and to some degree in nearly } \\
\text { every individual studied. } \\
\text { A lack of strong attachments and feelings of } \\
\text { alienation seemed to characterise the lives of } \\
\text { some of the individuals studied. } \\
\text { - Loneliness and anxiety seemed most } \\
\text { pronounced and were most obvious to the } \\
\text { investigator. } \\
\text { Researcher concludes that loneliness could } \\
\text { very likely be a cause of drug abuse. }\end{array}$ & Poor \\
\hline
\end{tabular}




\begin{tabular}{|c|c|c|c|c|c|}
\hline & & $\begin{array}{l}\text { Substance use: Not } \\
\text { reported ("drug users") }\end{array}$ & $\begin{array}{l}\text { completed the interviews at the counselling } \\
\text { laboratory in Montana State University. }\end{array}$ & & \\
\hline $\begin{array}{l}\text { Harris KS, } 1983 \\
{[59]}\end{array}$ & $\begin{array}{l}\text { To examine how alcoholism } \\
\text { related to development in the } \\
\text { areas of egocentrism, ego } \\
\text { identity and intimacy. }\end{array}$ & $\begin{array}{l}\text { N: } 72 ; \text { Alcoholic group: } \\
26 \text { (13 male, } 13 \text { female); } \\
\text { Non-alcoholic group: } 26 \\
\text { (13 male, } 13 \text { female); } \\
\text { Recovered group: } 20(9 \\
\text { male, } 11 \text { female) } \\
\text { Response rate: Not } \\
\text { reported } \\
\text { Country: America } \\
\text { Gender: Male and female } \\
\text { Age: } 18-27 ; \text { Alcoholic } \\
\text { group (M=19.81); Non- } \\
\text { alcoholic group (M=20); } \\
\text { Recovered group } \\
\text { (M=22.55) } \\
\text { Substance use: Alcohol }\end{array}$ & $\begin{array}{l}\text { Design: Cross-sectional } \\
\text { Setting: University classes ('Alcoholic ' and 'Non- } \\
\text { alcoholic' groups); AA meetings (Recovered } \\
\text { group) } \\
\text { Year: Not reported } \\
\text { Procedure: Participants invited at university class } \\
\text { and questionnaire packs distributed. Recovered } \\
\text { group approached at AA meetings and completed } \\
\text { same questionnaire pack (2 participants from } \\
\text { recovered group were recruited at the university) }\end{array}$ & $\begin{array}{l}\quad \text { No difference in loneliness across groups (non- } \\
\text { alcoholic, alcoholic, or recovered alcoholic). } \\
\text { No differences in loneliness across gender. } \\
\text { - } \quad \text { Concluded that in general, loneliness did not } \\
\text { seem to be a factor in the developmental delay } \\
\text { predicted for the alcoholic group. }\end{array}$ & Fair \\
\hline $\begin{array}{l}\text { Hornquist JO, } \\
\text { Akerlind I, } 1987 \\
\text { [60] }\end{array}$ & $\begin{array}{l}\text { To extend a preceding } \\
\text { correlational analysis of } \\
\text { loneliness to clinical and } \\
\text { psychological parameters in a } \\
\text { sample of } 95 \text { alcohol users. }\end{array}$ & $\begin{array}{l}\text { N: } 95 \text { ( } 88 \text { males, } 7 \\
\text { females) } \\
\text { Sample 1: } 61 \text { ( } 54 \text { males, } 7 \\
\text { females) } \\
\text { Sample 2: } 34 \text { (all males) } \\
\text { Response rate: } 82 \% \\
\text { Country: Sweden } \\
\text { Gender: Male and female } \\
\text { Age: } 24-60 \text { ( } M=44.5 \text {, } \\
S D=10.2 \text { ) } \\
\text { Substance use: Alcohol }\end{array}$ & $\begin{array}{l}\text { Design: Longitudinal } \\
\text { Setting: Community/Inpatient alcoholism } \\
\text { treatment service, Sociomedical outpatient clinic, } \\
\text { Psychiatric outpatient clinic, Vocational } \\
\text { rehabilitation service. } \\
\text { Year: } 1978 \text { and } 1979 \text { cross sectional data } \\
\text { collected (then again at two-year interval) } \\
\text { Procedure: Participants were first-time applicants } \\
\text { for disability pension. Participants were examined } \\
\text { twice with an approximate interval of two years. } \\
\text { Self-rating scales were used as well as broader } \\
\text { medical-psychological examination, including } \\
\text { clinical methods such as mental test, interview, } \\
\text { judgment by psychiatrist and biochemical test. }\end{array}$ & $\begin{array}{l}\text { Intellectual ability: } \\
\text { - Achievement on mental tests was not related to } \\
\text { feelings of loneliness. } \\
\text { Wellbeing: } \\
\text { - Loneliness found to be related to indolence, } \\
\text { life dissatisfaction, inferiority, self-esteem and } \\
\text { negative ego-concept. } \\
\text { A perception of ill treatment from others was } \\
\text { one of the strongest correlates of loneliness in } \\
\text { the study. } \\
\text { Psychiatric symptoms: } \\
\text { - Suicidal thoughts, sadness or depression, } \\
\text { autonomic disturbances, anxiety or tension, } \\
\text { emotional inhibition, lassitude, indecision, } \\
\text { sexual and sleep disturbances were stable } \\
\text { correlates with loneliness. } \\
\text { Characteristics of alcohol use: } \\
\text { - Loneliness was related to higher alcohol } \\
\text { consumption, delirium, and blackouts. }\end{array}$ & Fair \\
\hline
\end{tabular}




\begin{tabular}{|c|c|c|c|c|c|}
\hline & & & & $\begin{array}{l}\text { - Loneliness was related to having a relative } \\
\text { with an alcohol use problem. }\end{array}$ & \\
\hline $\begin{array}{l}\text { Hornquist JO, } \\
\text { Elton HF, } 1983 \\
{[55]}\end{array}$ & $\begin{array}{l}\text { To determine what changes in } \\
\text { quality of life occur when } \\
\text { people who use alcohol are } \\
\text { granted disability pension. }\end{array}$ & $\begin{array}{l}\text { N: Pensioned people who } \\
\text { use alcohol=78; } \\
\text { Pensioned people who do } \\
\text { not use alcohol=27; } \\
\text { Rehabilitators=30 } \\
\text { Response rate: } \\
\text { Pensioned alcohol group: } \\
78 \% \text { at baseline, } 92 \% \text { at } \\
\text { follow-up } \\
\text { Pensioned non-alcohol } \\
\text { group: } 85 \% \text { at follow-up } \\
\text { Rehabilitators: } 97 \% \text { at } 2- \\
\text { year follow-up. } \\
\text { Country: Sweden } \\
\text { Gender: Male and female } \\
\text { Age: } 20-60 \text { years } \\
\text { Substance use: Alcohol }\end{array}$ & $\begin{array}{l}\text { Design: Longitudinal } \\
\text { Setting: Community/ Inpatient alcoholism } \\
\text { treatment service/ Sociomedical outpatient clinic/ } \\
\text { Psychiatric outpatient clinic/ Vocational } \\
\text { rehabilitation service. } \\
\text { Not clearly stated where "pensioned users" group } \\
\text { was recruited. } \\
\text { Year: 1978-1982 } \\
\text { Procedure: Participants were people who had } \\
\text { applied for disability pension for the first time. } \\
\text { Three groups determined: (i) pensioned alcohol } \\
\text { use group; (ii) pensioned non-alcohol use group; } \\
\text { (iii) rehabilitators recruited from either: inpatient } \\
\text { treatment, accessing treatment at socio-medical } \\
\text { clinic, psychiatric clinic, vocational } \\
\text { rehabilitation). Groups were matched for age, sex, } \\
\text { and type of pension granted (e.g. back issues, } \\
\text { heart disease). Participants' background, social } \\
\text { network, daily activities, material situation and } \\
\text { structured situation, abuse of alcohol, psychiatric } \\
\text { status, wellbeing, mental tests and laboratory } \\
\text { studies were investigated at both time points. }\end{array}$ & $\begin{array}{l}\text { - Feelings of loneliness in pensioned alcohol } \\
\text { using group diminished over two-year period. } \\
\text { Not reported whether feelings of loneliness } \\
\text { also reduced for the "pensioned non-users" and } \\
\text { "rehabilitators" groups. } \\
\text { - This study does not report where "pensioned } \\
\text { users" were recruited from/ if they were } \\
\text { accessing treatment across this two-year } \\
\text { interval. As such, comments about the } \\
\text { potential effects of substance dependence } \\
\text { treatment on reduced loneliness cannot be } \\
\text { determined. } \\
\text { Functional disability of pensioned alcohol } \\
\text { using group does not change, yet general } \\
\text { wellbeing and psychiatric status does change } \\
\text { over two-year period. }\end{array}$ & Fair \\
\hline $\begin{array}{l}\text { Hörnquist JO, } \\
\text { Hansson B, } \\
\text { Akerlind I, } 1988 \\
{[61]}\end{array}$ & $\begin{array}{l}\text { To determine variables } \\
\text { predictive of a regained } \\
\text { working capacity in alcohol } \\
\text { users undergoing } \\
\text { rehabilitation. Variables } \\
\text { included: psychological, } \\
\text { attitudinal, behavioural, use } \\
\text { characteristics, psychiatric and } \\
\text { biochemical variables. }\end{array}$ & $\begin{array}{l}\text { N: } 34 \text { (all male) } \\
\text { Response rate: Not } \\
\text { reported } \\
\text { Country: Sweden } \\
\text { Gender: Male } \\
\text { Age: } 24-60(M=41.5 \text {, } \\
S D=10.5) \\
\text { Substance use: Alcohol }\end{array}$ & $\begin{array}{l}\text { Design: Longitudinal } \\
\text { Setting: Inpatient alcoholism treatment service/ } \\
\text { Sociomedical outpatient clinic/ Psychiatric } \\
\text { outpatient clinic/ Vocational rehabilitation } \\
\text { service. } \\
\text { Year: Baseline data collected } 1978 \text { and } 1979 \text { then } \\
\text { followed up after two-years } \\
\text { Procedure: The people who use alcohol were not } \\
\text { being given any special method of treatment } \\
\text { within the frame of this study but followed the } \\
\text { ordinary routines at their different institutes of }\end{array}$ & $\begin{array}{l}\text { Loneliness was the most significant predictor } \\
\text { of the subsequent vocational situation of } \\
\text { people who use alcohol. } \\
\text { Possibility of a better vocational outcome was } \\
\text { strengthened when the individual had no } \\
\text { drinking buddies and did not feel lonely. } \\
\text { The user who actually is alone but does not } \\
\text { feel lonely seems to be best equipped for } \\
\text { rehabilitation. }\end{array}$ & Fair \\
\hline
\end{tabular}




\begin{tabular}{|c|c|c|c|c|c|}
\hline & & & $\begin{array}{l}\text { treatment. Self-rating scales were completed at } \\
\text { both time points. }\end{array}$ & & \\
\hline $\begin{array}{l}\text { Hosseinbor M, } \\
\text { Yassini ASM, } \\
\text { Bakhshani S, } \\
\text { Bakhshani S, } \\
2014 \text { [62] }\end{array}$ & $\begin{array}{l}\text { To assess emotional, social, } \\
\text { romantic, and familial } \\
\text { dimensions of loneliness in } \\
\text { people who use drugs and } \\
\text { people who do not use drugs. }\end{array}$ & 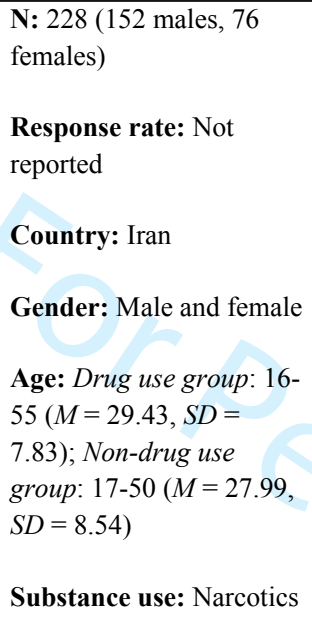 & $\begin{array}{l}\text { Design: Cross-sectional } \\
\text { Setting: Inpatient mental health treatment service } \\
\text { Year: Not reported } \\
\text { Procedure: Drug use group were enrolled } \\
\text { through random sampling method, and individuals } \\
\text { without history of using narcotic drugs were } \\
\text { selected through available sampling method from } \\
\text { drug use groups companions, students or staff of } \\
\text { the Baharan Psychiatric Hospital as non-drug use } \\
\text { group. All participants completed a clinical } \\
\text { interview and the loneliness scale. }\end{array}$ & $\begin{array}{l}\text { - Individuals diagnosed with substance } \\
\text { dependency scored higher on the romantic, } \\
\text { family, social, and emotional subscales of } \\
\text { SELSA than those of individuals without } \\
\text { substance dependency. } \\
\text { No significant difference between substance } \\
\text { dependent men and women on loneliness } \\
\text { scores } \\
\text { Significant difference between scores of non- } \\
\text { dependent men and women on romantic } \\
\text { subscale. } \\
\text { Social and emotional feelings of loneliness } \\
\text { deemed to be a high-risk factor for initiation of } \\
\text { drug use and its maintenance }\end{array}$ & Fair \\
\hline $\begin{array}{l}\text { Ingram I, Kelly } \\
\text { PJ, Deane FP, } \\
\text { Baker AL, } \\
\text { Raftery DK, } 2018 \\
{[22]}\end{array}$ & $\begin{array}{l}\text { To validate the SELSA-S } \\
\text { measure of loneliness for use } \\
\text { in substance dependent } \\
\text { treatment populations. The } \\
\text { study also aimed to determine } \\
\text { which demographic and } \\
\text { physical and mental health } \\
\text { variables were related to } \\
\text { loneliness. }\end{array}$ & $\begin{array}{l}\text { N: } 346 \\
\text { Response rate: } 91 \% \\
\text { Country: Australia } \\
\text { Gender: Male and female } \\
\text { Age: } M=37.71, S D=9.85 \\
\text { Substance use: Alcohol } \\
\text { and other drugs }\end{array}$ & $\begin{array}{l}\text { Design: Cross-sectional } \\
\text { Setting: Inpatient substance dependence treatment } \\
\text { service } \\
\text { Year: } 2017 \\
\text { Procedure: At each service, all residents were } \\
\text { invited to attend a meeting where the study was } \\
\text { explained. Completion of the anonymous surveys } \\
\text { indicated tacit consent was given. Surveys took } 30 \\
\text { minutes to complete. }\end{array}$ & $\begin{array}{l}\text { Further research needed to determine the } \\
\text { validity of the SELSA-S measure for use with } \\
\text { substance-dependent populations. } \\
\text { Substance-dependent populations experience } \\
\text { higher rates of loneliness compared with the } \\
\text { general population. } \\
\text { Frequency of loneliness was } 79 \%, 69 \% \\
\text { reported loneliness to be problematic. } \\
\text { Loneliness appeared to be primarily } \\
\text { experienced in the form of romantic loneliness. } \\
\text { - Higher psychological distress and lower } \\
\text { quality of life were associated with higher } \\
\text { loneliness scores. } \\
\text { Higher levels of loneliness were related to } \\
\text { poorer mental health and poorer physical } \\
\text { health. }\end{array}$ & Fair \\
\hline $\begin{array}{l}\text { Itzick M, Segal } \\
\text { JN, Possick C, } \\
2019 \text { [63] }\end{array}$ & $\begin{array}{l}\text { To use a contextual, } \\
\text { ecosystemic framework to } \\
\text { explore the experience and } \\
\text { meaning of relationships, }\end{array}$ & $\begin{array}{l}\text { N: } 12 \\
\text { Response rate: Not }\end{array}$ & $\begin{array}{l}\text { Design: Cross-sectional/ Qualitative } \\
\text { Setting: Narcotics Anonymous Groups }\end{array}$ & $\begin{array}{l}\text { Loneliness was the dominant feeling expressed } \\
\text { by most of the women }(n=9) \text {. } \\
\text { Drugs were often used as a way to escape } \\
\text { overwhelming feelings of loneliness, but }\end{array}$ & Fair \\
\hline
\end{tabular}




\begin{tabular}{|c|c|c|c|c|c|}
\hline & $\begin{array}{l}\text { amongst women experiencing } \\
\text { problems with substances. }\end{array}$ & $\begin{array}{l}\text { reported } \\
\text { Country: Israel } \\
\text { Gender: Female } \\
\text { Age: } 20-33 \\
\text { Substance use: Narcotics }\end{array}$ & $\begin{array}{l}\text { Year: Not reported } \\
\text { Procedure: Participants recruited through } \\
\text { outreach programs. The interview began with a } \\
\text { general invitation for the women to tell their life } \\
\text { stories. Participants then questioned about their } \\
\text { relationships with significant others in the past } \\
\text { and the present. Interviews were } 1-1.5 \text { hours in } \\
\text { duration. The interviews were recorded and } \\
\text { transcribed verbatim. }\end{array}$ & $\begin{array}{l}\text { ultimately did not help. } \\
\text { It seems that the loneliness expressed by the } \\
\text { women stemmed from a feeling that no one } \\
\text { really sees them. It may also develop as the } \\
\text { women retreat inward, distancing themselves } \\
\text { from others as a result of the trauma they } \\
\text { experienced in close relationships. }\end{array}$ & \\
\hline $\begin{array}{l}\text { Johnson RA, } \\
1985 \text { [33] }\end{array}$ & $\begin{array}{l}\text { To conduct an exploratory } \\
\text { study to: (i) investigate the } \\
\text { experience of loneliness } \\
\text { among people who are } \\
\text { dependent on alcohol; and (ii) } \\
\text { to evaluate the effectiveness of } \\
\text { an existential form of group } \\
\text { therapy (Logoanalysis). }\end{array}$ & $\begin{array}{l}\text { N: Study One: 56; Study } \\
\text { Two: } 20 \text { (10 in treatment } \\
\text { and } 10 \text { in control) } \\
\text { Response rate: Study } \\
\text { Two treatment group } 71 \% \\
\text { (not reported for Study } \\
\text { one or control condition } \\
\text { of Study Two). } \\
\text { Country: America } \\
\text { Gender: Male } \\
\text { Age: } \text { Baseline: } 27-62 \\
\text { ( } M=39.91) \\
\text { Experimental: Treatment } \\
\text { condition } 29-58 \\
\text { ( } M=41.10) \text {; Control } \\
\text { condition, } 29-63 \\
\text { (M=42.10) } \\
\text { Substance use: Alcohol }\end{array}$ & $\begin{array}{l}\text { Design: Cross-sectional } \\
\text { Setting: Inpatient substance dependence treatment } \\
\text { service } \\
\text { Year: Not reported } \\
\text { Procedure: Participants invited to participate } \\
\text { during routine intake interviews conducted at the } \\
\text { time of admission to the six-week inpatient } \\
\text { alcohol treatment program at a large Veterans } \\
\text { Administration neuropsychiatric hospital. The } \\
\text { study was conducted in two phases, baseline and } \\
\text { experimental. Baseline - self-report measures to } \\
\text { compare alcoholic subjects and other identified } \\
\text { groups (e.g. college students). Experimental - } \\
\text { compared treatment group with control subjects. } \\
\text { Participants enrolled on a voluntary basis in the } \\
\text { two-week, daily group based on the principles of } \\
\text { Logoanalysis. Baseline questionnaires completed } \\
\text { and a second administration of the scales took } \\
\text { place two weeks later at the end of the group } \\
\text { program. Logoanalysis group ran for one hour a } \\
\text { day. }\end{array}$ & $\begin{array}{l}\text { Study One: } \\
\text { - Loneliness was slightly higher than reported } \\
\text { for college students, but equal to or lower than } \\
\text { those reported for various groups of "high risk" } \\
\text { adults. } \\
\text { - } \quad \text { Loneliness unrelated to age } \\
\text { - Loneliness related to shyness, depression and } \\
\text { purpose in life } \\
\text { Loneliness related to number of friendships } \\
\text { and satisfaction of friendships } \\
\text { - Loneliness not related to frequency of contact } \\
\text { with friendships } \\
\text { Loneliness was also negatively related to the } \\
\text { degree of intimacy felt in romantic } \\
\text { relationships, frequency of contact with } \\
\text { romantic partners, and the amount of } \\
\text { satisfaction experienced } \\
\text { None of the characteristics associated with } \\
\text { family relationships was significantly related to } \\
\text { loneliness } \\
\text { Study Two } \\
\text { Logoanalysis was not found to be effective in } \\
\text { the alleviation of loneliness, nor did it affect } \\
\text { any of the other variables of interest in the } \\
\text { present study. }\end{array}$ & Fair \\
\hline
\end{tabular}




\begin{tabular}{|c|c|c|c|c|c|}
\hline $\begin{array}{l}\text { Kuerbis A, } \\
\text { Mereish EH, } \\
\text { Hayes M, Davis } \\
\text { CM, Sijing S, } \\
\text { Morgenstern J, } \\
\text { Shao S, } 2017 \text { [64] }\end{array}$ & $\begin{array}{l}\text { To explore how coping and } \\
\text { social factors (i.e. loneliness) } \\
\text { mediate the relationships } \\
\text { between internalised } \\
\text { heterosexism and health } \\
\text { outcomes. }\end{array}$ & $\begin{array}{l}\text { N: } 198 \\
\text { Response rate: } 49 \% \text { at } \\
\text { baseline, } 86.4 \% \text { at } 3 \\
\text { month follow-up, } 96 \% 9 \\
\text { months follow-up } \\
\text { Country: America } \\
\text { Gender: Male } \\
\text { Age: "participants were } \\
\text { about } 36 \text { years old" } \\
\text { Substance use: Alcohol }\end{array}$ & $\begin{array}{l}\text { Design: Longitudinal } \\
\text { Setting: Community ( } 88 \% \text { Alcohol Use Disorder } \\
\text { diagnosis, } 11 \% \text { met alcohol abuse criteria) } \\
\text { Year: Not reported } \\
\text { Procedure: Recruitment strategies included } \\
\text { online and community-based advertising. } \\
\text { Participants were randomly assigned to two } \\
\text { possible } 12 \text {-week treatments: (a) } 4 \text { sessions of } \\
\text { motivational interviewing or (b) } 12 \text { sessions of } \\
\text { motivational interviewing plus behavioural self- } \\
\text { control therapy. All groups were followed at } \\
\text { equivalent time points. Follow-up interviews were } \\
\text { implemented at } 3 \text { and } 9 \text { months after baseline. }\end{array}$ & $\begin{array}{l}\text { - Loneliness was found to mediate the } \\
\text { relationship between internalised heterosexism } \\
\text { and alcohol problems. } \\
\text { Concluded that addressing loneliness as a } \\
\text { potential risk factor for alcohol problems may } \\
\text { be crucial in preventing alcohol problems and } \\
\text { psychological distress }\end{array}$ & Good \\
\hline $\begin{array}{l}\text { Kuerbis A, } \\
\text { Padovano HT, } \\
\text { Shao SJ, Houser } \\
\text { J, Muench FJ, } \\
\text { Morgenstern J, } \\
2018 \text { [65] }\end{array}$ & $\begin{array}{l}\text { This study used secondary data } \\
\text { analysis to test whether age } \\
\text { moderated relationships } \\
\text { between variables (i.e. } \\
\text { loneliness) and drinking } \\
\text { among problem drinkers. }\end{array}$ & $\begin{array}{l}\text { N: } 139(56.8 \% \text { female, } \\
43.2 \% \text { male) } \\
\text { Response rate: Not } \\
\text { reported } \\
\text { Country: America } \\
\text { Gender: Male and female } \\
\text { Age: } 20-73 \text { ( } M=43.2 \text {, } \\
S D=12.5) \\
\text { Substance use: Alcohol }\end{array}$ & $\begin{array}{l}\text { Design: Cross-sectional cohort } \\
\text { Setting: Community } \\
\text { Year: Not reported } \\
\text { Procedure: Participants recruited using } \\
\text { advertising online and in local media. Participants } \\
\text { had to have a current Alcohol Use Disorder. } \\
\text { Participants completed a series of standard, global } \\
\text { self-report assessments. Ecological momentary } \\
\text { assessment (EMA) online surveys completed } \\
\text { daily over } 7 \text { days prior to randomisation. } \\
\text { Participants were then assessed again at baseline, } \\
\text { the point of randomisation. }\end{array}$ & $\begin{array}{l}\text { - Loneliness affected daily drinking across all } \\
\text { ages equally } \\
\text { - Older participants reported being less lonely. }\end{array}$ & Poor \\
\hline $\begin{array}{l}\text { Li F, Xu Y, Zhu J, } \\
\text { Lu J, Zhong B, } \\
2017 \text { [66] }\end{array}$ & $\begin{array}{l}\text { This study examined the } \\
\text { association between loneliness } \\
\text { and pain intensity in people } \\
\text { who use heroin receiving } \\
\text { MMT }\end{array}$ & $\begin{array}{l}\text { N: } 603 \text { (68.3\% males, } \\
31.7 \% \text { females) } \\
\text { Response rate: Not } \\
\text { reported } \\
\text { Country: China } \\
\text { Gender: Male and female }\end{array}$ & $\begin{array}{l}\text { Design: Cross-sectional } \\
\text { Setting: Outpatient substance dependence } \\
\text { treatment services } \\
\text { Year: } 2009-2010 \\
\text { Procedure: The study consecutively enrolled } \\
\text { adults who use heroin who met DSM-IV criteria } \\
\text { for a lifetime diagnosis of heroin dependence. }\end{array}$ & $\begin{array}{l}\text { - Loneliness was significantly associated with an } \\
\text { increase in pain intensity } \\
\text { After controlling for the potential confounding } \\
\text { effects of other covariates, loneliness remained } \\
\text { significantly associated with pain, suggesting } \\
\text { an independent effect of loneliness on pain in } \\
\text { people who use heroin. } \\
\text { Concluded loneliness is a significant } \\
\text { contributor to increased pain intensity. }\end{array}$ & Fair \\
\hline
\end{tabular}




\begin{tabular}{|c|c|c|c|c|c|}
\hline & & $\begin{array}{l}\text { Age: } M=38.1, S D=7.0 \\
\text { Substance use: Opioids }\end{array}$ & Self-administered questionnaires were completed. & & \\
\hline $\begin{array}{l}\text { Li H, Zhong B, } \\
\text { Xu Y, Zhu J, Lu } \\
\text { J, } 2017 \text { [67] }\end{array}$ & $\begin{array}{l}\text { To examine the impact of } \\
\text { loneliness on sleep patterns in } \\
\text { a sample of Heroin Dependent } \\
\text { Patients receiving MMT }\end{array}$ & $\begin{array}{l}\text { N: } 603 \text { ( } 68.3 \% \text { males, } \\
31.7 \% \text { females) } \\
\text { Response rate: Not } \\
\text { reported } \\
\text { Country: China } \\
\text { Gender: Male and female } \\
\text { Age: } 21-59 \text { ( } M=38.1 \\
S D=7.0) \\
\text { Substance use: Opioids }\end{array}$ & $\begin{array}{l}\text { Design: Cross-sectional } \\
\text { Setting: Outpatient substance dependence } \\
\text { treatment services } \\
\text { Year: 2009-2010 } \\
\text { Procedure: The study consecutively enrolled } \\
\text { adults who use heroin who met DSM-IV criteria } \\
\text { for a lifetime diagnosis of heroin dependence and } \\
\text { were taking methadone for drug rehabilitation. } \\
\text { Self-administered questionnaires were completed. }\end{array}$ & $\begin{array}{l}\text { Prevalence of loneliness was } 55.9 \% \text { among } \\
\text { people with heroin dependence accessing } \\
\text { MMT clinics. } \\
\text { There was a significant association between } \\
\text { loneliness and poor sleep in terms of quality } \\
\text { and quantity, including longer sleep latency, } \\
\text { shorter sleep duration, and lower sleep } \\
\text { efficiency, indicating that loneliness may } \\
\text { exacerbates sleep disturbance. }\end{array}$ & Fair \\
\hline $\begin{array}{l}\text { Medora NP, } 1983 \\
{[68]}\end{array}$ & $\begin{array}{l}\text { (i) To determine the extent of } \\
\text { loneliness among alcohol } \\
\text { dependent individuals. (ii) To } \\
\text { assess loneliness in relation to } \\
\text { a range of demographic health } \\
\text { and social variables. (iii) To } \\
\text { determine whether differences } \\
\text { in loneliness exist amongst } \\
\text { different populations. }\end{array}$ & $\begin{array}{l}\text { N: } 152 \text { ( } 92 \text { Males, } 60 \\
\text { Females) } \\
\text { Response rate: } 61 \% \\
\text { Country: America } \\
\text { Gender: Male and female } \\
\text { Age: } 19-75 \\
\text { Substance use: Alcohol }\end{array}$ & $\begin{array}{l}\text { Design: Cross-sectional } \\
\text { Setting: Participants were undergoing treatment } \\
\text { for alcoholism in seven alcohol rehabilitation } \\
\text { centres (not reported if inpatient or outpatient } \\
\text { settings). } \\
\text { Year: Not reported } \\
\text { Procedure: Questionnaires distributed at services } \\
\text { by counsellors at the service. Investigator } \\
\text { provided 'de-briefing' sessions following } \\
\text { completion of the anonymous questionnaire } \\
\text { whereby the objectives of the study were } \\
\text { explained for interested participants. }\end{array}$ & $\begin{array}{l}\text { - Mean loneliness score was higher than all other } \\
\text { samples, except 'low-income single adolescent } \\
\text { mother' group. } \\
\text { Best predictors of loneliness were: self-esteem, } \\
\text { age, self-rated marital satisfaction. } \\
\text { Age: Individuals aged 56-65 years were found } \\
\text { to be less lonely than those } 15-45 \text { years. } \\
\text { Gender: Females had higher loneliness scores } \\
\text { than males. } \\
\text { Marital status: Individuals who were divorced } \\
\text { or remarried had highest loneliness scores, } \\
\text { while married or de facto had lowest loneliness } \\
\text { scores and satisfaction with marital status was } \\
\text { related to loneliness. } \\
\text { Health: self-rated good/excellent health was } \\
\text { related to lower loneliness scores, and poor } \\
\text { health was related to higher loneliness scores } \\
\text { Mental health: Loneliness was related to self- } \\
\text { esteem; Difference in loneliness scores } \\
\text { between people who experience happiness in } \\
\text { past year and those who did not. } \\
\text { Social: Loneliness related to difficulty making } \\
\text { friends. People who went out "with relatives" } \\
\text { were found to be more lonely than those who } \\
\text { went out with a date, or with friends } \\
\text { Alcohol history: Difference found for }\end{array}$ & Fair \\
\hline
\end{tabular}




\begin{tabular}{|c|c|c|c|c|c|}
\hline & & & & $\begin{array}{l}\text { loneliness between people who had past } \\
\text { history of alcoholism in the family, and those } \\
\text { who did not. Relationship found between } \\
\text { number of years alcohol consumed and } \\
\text { loneliness. } \\
\text { Other: Loneliness related to job satisfaction. }\end{array}$ & \\
\hline $\begin{array}{l}\text { Medora NP, } \\
\text { Woodward JC, } \\
1990 \text { [69] }\end{array}$ & $\begin{array}{l}\text { The extent of loneliness was } \\
\text { investigated in relationship to } \\
\text { gender, religiosity, age, } \\
\text { education, adequacy of } \\
\text { income, social class, number } \\
\text { of close friends, self-rated } \\
\text { health, ease in making friends, } \\
\text { and frequency of participating } \\
\text { in social activities. }\end{array}$ & $\begin{array}{l}\text { N: } 152 \text { ( } 92 \text { males, } 60 \\
\text { females) } \\
\text { Response rate: Not } \\
\text { reported } \\
\text { Country: America } \\
\text { Gender: Male and female } \\
\text { Age: } 19 \text { - } 55 \text { years } \\
\text { Substance use: Alcohol }\end{array}$ & $\begin{array}{l}\text { Design: Cross-sectional } \\
\text { Setting: Participants undergoing treatment in } \\
\text { seven alcohol rehabilitation centres (not reported } \\
\text { if inpatient or outpatient settings) } \\
\text { Year: Not reported } \\
\text { Procedure: Questionnaires distributed at services } \\
\text { by counsellors at the service. }\end{array}$ & $\begin{array}{l}\text { - Younger persons were found to be } \\
\text { significantly lonelier than older persons } \\
\text { - Women were significantly lonelier than men. } \\
\text { There was a relationship between loneliness } \\
\text { and self-rated state of health and ease in } \\
\text { making friends. } \\
\text { The following variables did not affect } \\
\text { loneliness--education, socioeconomic status, } \\
\text { adequacy of income, religiosity, number of } \\
\text { close friends, and frequency of going out for } \\
\text { social reasons. }\end{array}$ & Fair \\
\hline $\begin{array}{l}\text { Medora NP, } \\
\text { Woodward JC, } \\
1991 \text { [70] }\end{array}$ & $\begin{array}{l}\text { Objective was to examine the } \\
\text { extent of loneliness in relation } \\
\text { to demographic and social } \\
\text { variables of participants } \\
\text { undergoing treatment at } \\
\text { alcohol rehabilitation centres. }\end{array}$ & $\begin{array}{l}\text { N: } 152 \text { ( } 92 \text { male, } 60 \\
\text { female) } \\
\text { Response rate: Not } \\
\text { reported } \\
\text { Country: America } \\
\text { Gender: Male and female } \\
\text { Age: } 19 \text { - } 55 \text { years } \\
\text { Substance use: Alcohol }\end{array}$ & $\begin{array}{l}\text { Design: Cross-sectional } \\
\text { Setting: Participants undergoing treatment in } \\
\text { seven alcohol rehabilitation centres (not reported } \\
\text { if inpatient or outpatient settings) } \\
\text { Year: Not reported } \\
\text { Procedure: Self-report questionnaires were } \\
\text { administered to participants at alcohol } \\
\text { rehabilitation centres. }\end{array}$ & $\begin{array}{l}\text { Females lonelier than males. } \\
\text { - } \quad \text { Negative relationship between loneliness and } \\
\text { self-rated marital satisfaction. } \\
\text { Awareness of history of alcoholism had higher } \\
\text { loneliness scores than people who were } \\
\text { unaware of a family history of alcoholism. } \\
\text { - } \quad \text { Negative relationship between loneliness and } \\
\text { self-esteem. } \\
\text { Negative relationship between loneliness and } \\
\text { number of year's alcohol has been consumed. } \\
\text { Higher ratings of happiness of the past year } \\
\text { ("very happy") were lonelier than people who } \\
\text { rated they were "happy". }\end{array}$ & Fair \\
\hline $\begin{array}{l}\text { Michaels AW, } \\
1982 \text { [71] }\end{array}$ & $\begin{array}{l}\text { To compare alcoholic and non- } \\
\text { alcoholic treatment } \\
\text { populations in terms of denial, } \\
\text { and to determine whether } \\
\text { denial is related to loneliness } \\
\text { and/or to alcoholism }\end{array}$ & $\begin{array}{l}\text { N: } 60 \text { ( } 36 \text { males, } 24 \\
\text { females) } \\
\text { Response rate: Not } \\
\text { reported } \\
\text { Country: America } \\
\text { Gender: Male and female }\end{array}$ & $\begin{array}{l}\text { Design: Cross-sectional } \\
\text { Setting: Outpatient substance dependence } \\
\text { treatment service; Outpatient mental health } \\
\text { treatment service } \\
\text { Year: Not reported } \\
\text { Procedure: Handout distributed in waiting rooms }\end{array}$ & $\begin{array}{l}\text { - Mean loneliness score were not significantly } \\
\text { different between groups } \\
\text { Among alcoholics: loneliness scores were } \\
\text { correlated with education and income, but not } \\
\text { correlated with age. } \\
\text { Among outpatients loneliness not correlated } \\
\text { with any demographic variables. } \\
\text { The higher the level of denial, the lower the } \\
\text { loneliness score } \\
\text { - The lower the level of denial, the higher the }\end{array}$ & Fair \\
\hline
\end{tabular}




\begin{tabular}{|c|c|c|c|c|c|}
\hline & & $\begin{array}{l}\text { Age: } 21-69(M=34) \\
\text { Substance use: Alcohol }\end{array}$ & $\begin{array}{l}\text { at the clinics to recruit participants. Participants } \\
\text { completed a survey pack in the waiting room. }\end{array}$ & $\begin{array}{l}\text { subject is likely to score on loneliness } \\
\text { Loneliness was found to correlate with need } \\
\text { for inpatient care. }\end{array}$ & \\
\hline $\begin{array}{l}\text { Neale J, } \\
\text { Tompkins CNE, } \\
\text { Strang J, } 2018 \\
{[72]}\end{array}$ & $\begin{array}{l}\text { The qualitative study aimed to } \\
\text { provide further insights into } \\
\text { relationships between peers in } \\
\text { residential substance use } \\
\text { treatment services }\end{array}$ & $\begin{array}{l}\text { N: } 21 \text { (13 males, } 8 \\
\text { females) } \\
\text { Response rate: Not } \\
\text { reported } \\
\text { Country: England } \\
\text { Gender: Male and female } \\
\text { Age: } 23-57 \\
\text { Substance use: Not } \\
\text { reported }\end{array}$ & $\begin{array}{l}\text { Design: Cross-sectional/qualitative } \\
\text { Setting: Inpatient substance dependence treatment } \\
\text { service } \\
\text { Year: 2015-2016 } \\
\text { Procedure: Member of the research team visited } \\
\text { treatment services to recruit current residents. } \\
\text { Staff at the services contacted former residents for } \\
\text { recruitment. Researcher then approached a } \\
\text { subgroup of those expressing interest. Semi- } \\
\text { structured interviews completed which asked } \\
\text { about backgrounds, substance use and experiences } \\
\text { of residential treatment, including relationships } \\
\text { with their peers. All interviews were audio- } \\
\text { recorded and transcribed verbatim. }\end{array}$ & $\begin{array}{l}\text { Contrary to expectations, few residents } \\
\text { described bonding with their peers. } \\
\text { Interpersonal differences polarised residents. } \\
\text { Residents more often reported isolation, } \\
\text { loneliness, wariness, bullying, manipulation, } \\
\text { intimidation, social distancing, tensions and } \\
\text { conflict. } \\
\text { Overall, findings undermine the notion of the } \\
\text { therapeutic community as a method of positive } \\
\text { behaviour change. }\end{array}$ & Good \\
\hline $\begin{array}{l}\text { Nerviano VJ, } \\
\text { Gross WF, } 1976 \\
{[73]}\end{array}$ & $\begin{array}{l}\text { Aim was a revision and/or } \\
\text { regrouping of Bradley's } 38 \\
\text { loneliness items for a } \\
\text { population of chronic } \\
\text { alcoholics. Evidence for the } \\
\text { discriminant and convergent } \\
\text { validity of newly derived } \\
\text { subscales was to be sought. }\end{array}$ & $\begin{array}{l}\text { N: } 349 \text { (all males) } \\
\text { Response rate: Not } \\
\text { reported } \\
\text { Country: America } \\
\text { Gender: Male } \\
\text { Age: } M=44 \\
\text { Substance use: Alcohol }\end{array}$ & $\begin{array}{l}\text { Design: Cross-sectional } \\
\text { Setting: Inpatient substance dependence treatment } \\
\text { service } \\
\text { Year: Not reported } \\
\text { Procedure: All participants were detoxified and } \\
\text { completed the assessment battery at time of } \\
\text { admission }\end{array}$ & $\begin{array}{l}\text { The Bradley scale, revised factor-analytically } \\
\text { into two correlated dimensions termed } \\
\text { Interpersonal Anxiety (LSI) and Sense of } \\
\text { Rejection and Abandonment (LS2), showed } \\
\text { many moderately high correlations. These } \\
\text { correlates were seen as highly supportive of the } \\
\text { construct validity of the new scales. } \\
\text { Overall, the experience of loneliness seems } \\
\text { more related to the degree of general success in } \\
\text { interpersonal relations than to single needs or } \\
\text { traits. } \\
\text { Loneliness correlated with personality } \\
\text { variables of: immature, interpersonally } \\
\text { inhibited, low impulse organisation, poor self- } \\
\text { presentation; high loneliness scores related to } \\
\text { high subjective distress and emotional } \\
\text { instability. } \\
\text { Consistent relationship of high loneliness } \\
\text { scores to the factor markers for PF Anxiety, an } \\
\text { indication of high subjective distress and } \\
\text { emotional instability. }\end{array}$ & Poor \\
\hline $\begin{array}{l}\text { Newton TF, De } \\
\text { La Garza R, }\end{array}$ & $\begin{array}{l}\text { To investigate perceptions of } \\
\text { the reasons for }\end{array}$ & N: 73 (12 females, 61 & Design: Cross-sectional & $\begin{array}{l}23 \% \text { of the sample reported using drugs 'very } \\
\text { much' to make bad feelings like boredom, }\end{array}$ & Fair \\
\hline
\end{tabular}




\begin{tabular}{|c|c|c|c|c|c|}
\hline $\begin{array}{l}\text { Kalechstein AD, } \\
\text { Tziortzis D, } \\
\text { Jacobsen CA, } \\
2009[74]\end{array}$ & methamphetamine use. & $\begin{array}{l}\text { males) } \\
\text { Response rate: Not } \\
\text { reported } \\
\text { Country: America } \\
\text { Gender: Male and female } \\
\text { Age: } M=36.3, S D=9.2 \\
\text { Substance use: } \\
\text { Methamphetamines }\end{array}$ & $\begin{array}{l}\text { Setting: Community (all participants met DSM- } \\
\text { IV criteria for methamphetamine-dependence) } \\
\text { Year: Not reported } \\
\text { Procedure: Participants completed an initial } \\
\text { battery of questionnaires and were then } \\
\text { administered a variety of assessments. At the time } \\
\text { of assessment, a toxicology screen was performed. }\end{array}$ & $\begin{array}{l}\text { loneliness, or apathy go away; while } 30.1 \% \text { of } \\
\text { the sample reported they did 'not at all'. } \\
26 \% \text { of the sample reported relapsing mostly to } \\
\text { make bad feelings like boredom, loneliness, or } \\
\text { apathy go away }\end{array}$ & \\
\hline $\begin{array}{l}\text { Perodeau GM, du } \\
\text { Fort GG, } 2000 \\
{[75]}\end{array}$ & $\begin{array}{l}\text { To compare elderly people } \\
\text { who use or do not use, } \\
\text { psychotropic drugs on mental } \\
\text { health and psychosocial } \\
\text { characteristics. }\end{array}$ & $\begin{array}{l}\text { N: } 199 \text { ( } 82.1 \% \text { female, } \\
17.9 \% \text { male) } \\
\text { Response rate: } 88 \% \\
\text { Country: Canada } \\
\text { Gender: Male and female } \\
\text { Age: } 62-98 \\
\text { Drug use group: } M=77.8 \text {, } \\
S D=7.8 ; \\
\text { Non-drug use group: } \\
M=80.9, S D=7.4 \\
\text { Substance use: } \\
\text { Psychotropic drugs (not } \\
\text { for medical purposes) }\end{array}$ & $\begin{array}{l}\text { Design: Cross-sectional } \\
\text { Setting: Community (People who use } \\
\text { psychotropic drugs were defined as individuals } \\
\text { who reported using one or more psychotropic } \\
\text { drugs in the preceding } 3 \text { months) } \\
\text { Year: Not reported } \\
\text { Procedure: Two 90-minute face-to-face } \\
\text { interviews were conducted in French or English } \\
\text { language, by experienced female interviewers in } \\
\text { the elder's home with a 1-week interval between } \\
\text { interviews. The first interview concerned health } \\
\text { patterns, and the second focused on psychosocial } \\
\text { issues. }\end{array}$ & $\begin{array}{l}\text { Feelings of loneliness reported by a higher } \\
\text { percentage of people who used psychotropic } \\
\text { drugs }(40 \%) \text { than people who did not use drugs } \\
(16 \%) \text {. } \\
\text { - Anxiety related to loneliness in people who } \\
\text { used drugs. } \\
\text { Depression related to loneliness in people who } \\
\text { use drugs. } \\
\text { People who use drugs appear to have a greater } \\
\text { sensitivity to perceived weaknesses in the } \\
\text { social support system than nonusers. }\end{array}$ & Fair \\
\hline $\begin{array}{l}\text { Price RH, Curlee- } \\
\text { Salisbury J, } 1975 \\
{[76]}\end{array}$ & $\begin{array}{l}\text { Examined different reactions } \\
\text { to treatment settings based on } \\
\text { responses of the patient group. } \\
\text { Additionally, this study aimed } \\
\text { to examine subsets of patients } \\
\text { who showed different patterns } \\
\text { of response to various }\end{array}$ & $\begin{array}{l}\text { N: } 51 \text { (all males) } \\
\text { Response rate: Not } \\
\text { reported } \\
\text { Country: America }\end{array}$ & $\begin{array}{l}\text { Design: Cross-sectional } \\
\text { Setting: Inpatient substance dependence treatment } \\
\text { service } \\
\text { Year: Not reported } \\
\text { Procedure: Patients tested individually within 3-4 }\end{array}$ & $\begin{array}{l}\text { - Conclusions do not specifically refer to } \\
\text { loneliness } \\
\text { Conclusions here have been inferred from } \\
\text { Table } 2 \text { of the source: it appears that loneliness } \\
\text { had one of highest ranks when people were in } \\
\text { hospital, and one of the lowest ranks } \\
\text { (compared to other domains such as } \\
\text { pleasantness, vigour, affiliation etc.) for other } \\
\text { aspects of alcoholism treatment. }\end{array}$ & Poor \\
\hline
\end{tabular}




\begin{tabular}{|c|c|c|c|c|c|}
\hline & treatment modalities. & $\begin{array}{l}\text { Gender: Male } \\
\text { Age: } 21-56(M=44) \\
\text { Substance use: Alcohol }\end{array}$ & $\begin{array}{l}\text { days discharge. Patients ranked } 8 \text { aspects of } \\
\text { treatment program on } 8 \text { response dimensions. } \\
\text { Patients also completed Minnesota Multiphasic } \\
\text { Personality Inventory (MMPI-II) and } 46 \text { the } \\
\text { Shipley Full Scale IQ and } 5 \text { the Quick test. } \\
\text { Loneliness was one response dimension that was } \\
\text { rated across } 8 \text { different treatment modalities (e.g. } \\
\text { group therapy, lecture, free time). }\end{array}$ & & \\
\hline $\begin{array}{l}\text { Schmidt DR, } \\
2002 \text { [77] }\end{array}$ & $\begin{array}{l}\text { To investigate the impact of a } \\
\text { recovery program for } \\
\text { recovering adult male addicts. } \\
\text { The research was divided into } \\
\text { etiological issues and } \\
\text { intervention strategy. Within } \\
\text { these two main sections three } \\
\text { primary areas were explored: } \\
\text { (i) loneliness and social } \\
\text { relationships; (ii) identity and } \\
\text { self-esteem issues; and (iii } \\
\text { self-control issues. }\end{array}$ & $\begin{array}{l}\text { N: } 5 \text { staff and } 13 \text { clients } \\
\text { Response rate: Not } \\
\text { reported } \\
\text { Country: America } \\
\text { Gender: Male and female } \\
\text { Age: Not reported } \\
\text { Substance use: All } \\
\text { substances }\end{array}$ & $\begin{array}{l}\text { Design: Cross-sectional/ Qualitative } \\
\text { Setting: Inpatient substance dependence treatment } \\
\text { service } \\
\text { Year: } 2001 \\
\text { Procedure: Qualitative cross-sectional interviews } \\
\text { were conducted in an ethnographic style asking } \\
\text { for description and probing within the answers } \\
\text { received. Compared the client interview findings } \\
\text { with staff interviews. }\end{array}$ & $\begin{array}{l}\text { - A lack of quality trusting relationships and } \\
\text { isolation when using substances were linked to } \\
\text { loneliness according to the staff interviewed. } \\
\text { Because of the detached and abusive way that } \\
\text { most were treated, they felt often like } \\
\text { "survivors" and "on their own" which included } \\
\text { feelings of loneliness. } \\
\text { Participants identified loneliness as being } \\
\text { linked to an urge to escape into drugs and } \\
\text { alcohol. } \\
\text { The staff and residents were in agreement that } \\
\text { there are problems of loneliness and social } \\
\text { relationships amongst almost all of the } \\
\text { residents. }\end{array}$ & Poor \\
\hline $\begin{array}{l}\text { Schonfeld L, } \\
\text { Dupree LW, } \\
\text { Rohrer GE, } 1995 \\
{[78]}\end{array}$ & $\begin{array}{l}\text { To determine pre-treatment } \\
\text { drinking behaviours of } \\
\text { younger and older people who } \\
\text { use alcohol, and to identify any } \\
\text { differences in antecedents to } \\
\text { drinking. }\end{array}$ & 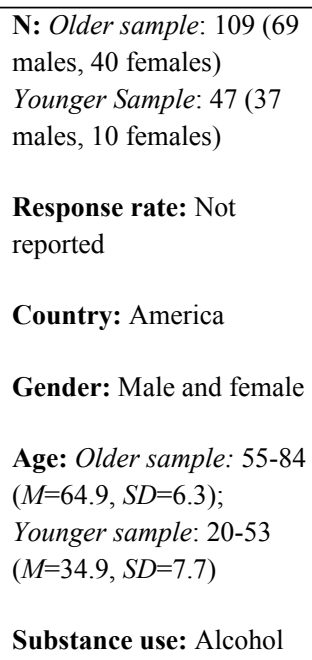 & $\begin{array}{l}\text { Design: Cross-sectional } \\
\text { Setting: Inpatient \& Outpatient substance } \\
\text { dependence treatment service } \\
\text { Year: Not reported } \\
\text { Procedure: Assessments administered by staff } \\
\text { via interviews. For the older sample, the } \\
\text { interview was conducted within first two-weeks of } \\
\text { program entry. In the younger sample, the } \\
\text { interview was conducted at any time during 6- } \\
\text { week stay. }\end{array}$ & $\begin{array}{l}\text { Older people who use alcohol were found to } \\
\text { drink in response to feelings of depression, } \\
\text { loneliness, and related interpersonal and } \\
\text { emotional states. } \\
\text { Younger people who use alcohol tended to } \\
\text { drink with other people, away from home, and } \\
\text { in response to a wider variety of antecedents. } \\
\text { Concluded that differences appear to exist in } \\
\text { terms of antecedent to alcohol abuse between } \\
\text { younger and older people who use alcohol. } \\
\text { Category including loneliness - "depressed, } \\
\text { lonely, and bored" - was determined to be an } \\
\text { antecedent to drinking alcohol for } 45 \% \text { of the } \\
\text { older sample, and } 21 \% \text { of the younger sample. }\end{array}$ & Fair \\
\hline
\end{tabular}




\begin{tabular}{|c|c|c|c|c|c|}
\hline $\begin{array}{l}\text { Siddique F, } \\
\text { Ahmad Mann A, } \\
\text { Ali T, } 2012 \text { [79] }\end{array}$ & $\begin{array}{l}\text { To investigate drug use } \\
\text { behaviour and its relationship } \\
\text { with social characteristics. }\end{array}$ & $\begin{array}{l}\text { N: Specific sample size } \\
\text { not reported ("a } \\
\text { proportion of } 500 \text { drug } \\
\text { users") } \\
\text { Response rate: Not } \\
\text { reported } \\
\text { Country: Pakistan } \\
\text { Gender: Male } \\
\text { Age: Not reported } \\
\text { Substance use: Not } \\
\text { reported }\end{array}$ & $\begin{array}{l}\text { Design: Cross-sectional } \\
\text { Setting: } 5 \text { government model drug abuse and } \\
\text { rehabilitation centres (not specified if inpatient or } \\
\text { outpatient) } \\
\text { Year: Not reported } \\
\text { Procedure: Participants were interviewed } \\
\text { randomly from a list of } 500 \text { potential participants } \\
\text { available at these centres. }\end{array}$ & $\begin{array}{l}\text { - Concluded that loneliness influenced the } \\
\text { behaviour of people who experience drug } \\
\text { dependence. } \\
\text { Conclusions made about loneliness and drug } \\
\text { use don't appear to be supported by the data } \\
\text { presented throughout the article }\end{array}$ & Poor \\
\hline $\begin{array}{l}\text { Van Hasselt VB, } \\
\text { Null JA, Kempton } \\
\text { T, Bukstein OG, } \\
1993[80]\end{array}$ & $\begin{array}{l}\text { To conduct an evaluation of } \\
\text { social skills and depression in } \\
\text { adolescents who use } \\
\text { substances. }\end{array}$ & $\begin{array}{l}\text { N: } 104 \text { ( } 53 \text { females, } 51 \\
\text { males) } \\
\text { Response rate: Not } \\
\text { reported } \\
\text { Country: America } \\
\text { Gender: Male and female } \\
\begin{array}{l}\text { Age: } 11.4-18.8 \text { years } \\
(M=15.3, S D=1.7)\end{array} \\
\text { Substance use: Not } \\
\text { reported }\end{array}$ & $\begin{array}{l}\text { Design: Cross-sectional } \\
\text { Setting: Inpatient mental health treatment service } \\
\text { Year: Not reported } \\
\text { Procedure: A self-report battery was } \\
\text { administered within the first week of admission } \\
\text { that assessed level of assertion, social satisfaction, } \\
\text { loneliness, depression, hopelessness, and self- } \\
\text { esteem. In addition, the relationship between } \\
\text { social skills and depression was examined. }\end{array}$ & $\begin{array}{l}\text { Higher levels of depression were related to less } \\
\text { assertion skill and increased loneliness. } \\
\text { Loneliness found to be correlated with } \\
\text { depression, hopelessness and self-esteem }\end{array}$ & Fair \\
\hline $\begin{array}{l}\text { Yang Y, Xu Y, } \\
\text { Chen W, Zhu J, } \\
\text { Lu J, Zhong B, } \\
2017 \text { [81] }\end{array}$ & $\begin{array}{l}\text { This study determined the } \\
\text { prevalence and socio- } \\
\text { demographic and clinical } \\
\text { correlates of loneliness and its } \\
\text { impact on quality of life in } \\
\text { Chinese heroin-dependent } \\
\text { patients receiving MMT. }\end{array}$ & $\begin{array}{l}\text { N: } 603(68.3 \% \text { female }) \\
\text { Response rate: } 92.5 \% \\
\text { Country: China } \\
\text { Gender: Male and female } \\
\text { Age: } 21-59(M=38.1 \text {, } \\
S D=7.0)\end{array}$ & $\begin{array}{l}\text { Design: Cross-sectional } \\
\text { Setting: Outpatient substance dependence } \\
\text { treatment services } \\
\text { Year: } 2015 \\
\text { Procedure: The cross-sectional survey was } \\
\text { conducted in three city-owned MMT clinics. }\end{array}$ & $\begin{array}{l}\text { Found a high prevalence of loneliness (55.9\%) } \\
\text { in Chinese heroin dependent patients receiving } \\
\text { MMT. } \\
\text { Efforts to reduce loneliness may be useful to } \\
\text { target on those who are unmarried, } \\
\text { unemployed, and depressed, and have religious } \\
\text { beliefs, get along with others poorly, and have } \\
\text { a history of injecting heroin. } \\
\text { Loneliness related to being unmarried, } \\
\text { unemployed, having religious beliefs. } \\
\text { - Loneliness related to having a history of } \\
\text { injecting heroin. } \\
\text { - Loneliness related to depression. }\end{array}$ & Fair \\
\hline
\end{tabular}




\begin{tabular}{|c|c|c|c|c|c|}
\hline & & Substance use: Opioids & & $\begin{array}{l}\text { - Those who got along poorly with others were } \\
\text { found to be lonelier. }\end{array}$ & \\
\hline Yeh M, 2002 [82] & $\begin{array}{l}\text { To examine the relationships } \\
\text { among and between global } \\
\text { loneliness, social loneliness, } \\
\text { and emotional loneliness, and } \\
\text { the degree/severity of alcohol } \\
\text { or marijuana use related } \\
\text { problems among referred } \\
\text { alcohol and marijuana users } \\
\text { and a random sample drawn } \\
\text { from the university's general } \\
\text { male student body. }\end{array}$ & $\begin{array}{l}\text { N: } 116 \text { (all males) } \\
\text { Experimental, N=49 } \\
\text { Control, N=67 } \\
\text { Response rate: } 91 \% \\
\text { Country: America } \\
\text { Gender: Male } \\
\text { Age: Not reported } \\
\text { Substance use: Alcohol } \\
\text { and marijuana }\end{array}$ & $\begin{array}{l}\text { Design: Cross-sectional } \\
\text { Setting: University/outpatient substance } \\
\text { dependence treatment service } \\
\text { Year: } 2000 \\
\text { Procedure: Participants were selected in two } \\
\text { different ways: (i) from a referral group sample } \\
\text { (experimental group); and (ii) from a random } \\
\text { sample (control or comparison group). A } \\
\text { purposive sampling design was used for recruiting } \\
\text { participants from the referral group. Participants } \\
\text { completed a survey including demographics, } \\
\text { UCLA-LS and substance use measure. }\end{array}$ & $\begin{array}{l}\text { - } \begin{array}{l}\text { No significant relationship found between drug } \\
\text { and alcohol score and the global loneliness } \\
\text { score, the emotional loneliness score, and the } \\
\text { social loneliness score, for both groups. } \\
\text { Significant relationships found among global, } \\
\text { emotional, and social loneliness scores for the } \\
\text { substance use group and the control group. } \\
\text { Significant difference between the substance } \\
\text { use group and the control group with respect to } \\
\text { the emotional loneliness score and the social } \\
\text { loneliness. } \\
\text { The control group had a higher social } \\
\text { loneliness score. } \\
\text { Substance use group had a higher emotional } \\
\text { loneliness score. } \\
\text { Within the substance use group, the marijuana } \\
\text { users were emotionally lonelier and had a } \\
\text { higher degree/severity of alcohol or marijuana } \\
\text { use related problems than alcohol users. } \\
\text { No difference in the global loneliness score } \\
\text { between the substance use group and the } \\
\text { control group. }\end{array} \\
\end{array}$ & Fair \\
\hline $\begin{array}{l}\text { Zhong B, Xu Y, } \\
\text { Zhu J, Liu X, } \\
2018 \text { [83] }\end{array}$ & $\begin{array}{l}\text { To examine the prevalence of } \\
\text { NSSI, its subtypes, and factors } \\
\text { significantly associated with } \\
\text { NSSI. }\end{array}$ & $\begin{array}{l}\text { N: } 652 \\
\text { Response rate: } 92.5 \% \\
\text { Country: China } \\
\text { Gender: Male and female } \\
\text { Age: } M=38.1, S D=7 \\
\text { Substance use: Heroin }\end{array}$ & $\begin{array}{l}\text { Design: Cross-sectional } \\
\text { Setting: Outpatient substance dependence } \\
\text { treatment services } \\
\text { Year: } 2009-2010 \\
\text { Procedure: Investigators reviewed medical charts } \\
\text { and interviewed patients for eligibility. All } \\
\text { patients independently and anonymously } \\
\text { completed the questionnaires. }\end{array}$ & $\begin{array}{l}\text { Relative to the no NSSI group, patients in the } \\
\text { NSSI group were more likely to feel lonely. } \\
\text { Loneliness was one factor found to be } \\
\text { significantly associated with non-suicidal self- } \\
\text { injury amongst this sample. }\end{array}$ & Fair \\
\hline
\end{tabular}

Adults, short version; TASC, Treatment Alternatives for Safe Communities; UCLA-LS, University of California, Los Angeles Loneliness Scale. 
Table 2. Measures of loneliness

\begin{tabular}{|c|c|}
\hline Measure used & Psychometric properties \\
\hline \multicolumn{2}{|l|}{ UCLA Loneliness Scale (Version 3) [51] } \\
\hline Armstrong JA, 2016 [48] & $\begin{array}{l}\text { Not reported for study sample. } \\
\text { Cited psychometric properties reported by Russell (1996) [51 (elderly population, aged }>65, n=301 \text { ) } \\
\text { Test-retest reliability: ICC }=0.73 \text { (fair) }\end{array}$ \\
\hline Britton PC, Conner KR, 2007 [50] & $\begin{array}{l}\text { Internal consistency: } \alpha=0.87 \text { (good) } \\
\text { Test-retest reliability: } \mathrm{ICC}=0.76 \text { (fair) } \\
\text { Cited psychometric properties reported by Russell (1996) [51]: } \\
\text { Internal consistency: } \alpha=0.89-0.94 \text { (excellent) } \\
\text { Test-retest reliability: } \text { ICC }=0.73 \text { (fair) } \\
\text { Criterion validity: negatively correlated with measure of belonging, } r=-0.67, P<0.001\end{array}$ \\
\hline Conner KR, Britton PC, Sworts LM, Joiner TE, 2007 [53] & $\begin{array}{l}\text { Internal consistency: } \alpha=0.87 \text { (good) } \\
\text { Test-retest reliability: } \mathrm{ICC}=0.76 \text { (fair) } \\
\text { Criterion validity: negatively correlated with measure of belonging, } r=-0.67, P<0.001 \text {, and burdensomeness and loneliness was } r=-0.67, P< \\
0.001 \text {. }\end{array}$ \\
\hline $\begin{array}{l}\text { Kuerbis A, Mereish EH, Hayes M, Davis CM, Sijing S, } \\
\text { Morgenstern J, Shao S, } 2017 \text { [64] }\end{array}$ & Internal consistency: $\alpha=0.91-0.93$ across three-month time frame (excellent) \\
\hline \multicolumn{2}{|l|}{ Revised UCLA Loneliness Scale [89] } \\
\hline Cao Q, Liang Y, 2017 [52] & $\begin{array}{l}\text { Internal Consistency: } \alpha=0.79 \text { (fair) } \\
\text { Cited psychometric properties reported by Russell et al. (1980) [89]: } \\
\text { Internal consistency: } \alpha=0.94 \text { (excellent) }\end{array}$ \\
\hline Essex EL, Petras D, Massat CR, 2007 [56] & Internal consistency: $\alpha=0.89$ (good) \\
\hline Evans TJ, $2010[57]$ & Measure used to identify eligible participants for the study. Not reported. \\
\hline Harris KS, 1983 [59] & $\begin{array}{l}\text { Internal consistency: } \alpha=0.94 \text { (excellent) } \\
\text { Cited psychometric properties reported by Russell et al. (1980) [89]: } \\
\text { Concurrent validity: UCLA correlated with Beck Depression Inventory, } r=0.62 \text {, and the Costello-Comrey Anxiety measure, } r=0.82\end{array}$ \\
\hline Johnson RA, 1985 [33] & $\begin{array}{l}\text { Measure used to identify eligible participants for the study. } \\
\text { Cited psychometrics reported by Russell } \text { et al. [89]: } \\
\text { Internal consistency: } \alpha=0.94 \text { (excellent) } \\
\text { Test-retest reliability: coefficient reported to be } 0.70 \text { over two months (fair) } \\
\text { Convergent validity: Revised UCLA correlated with original UCLA scale, } r=0.91\end{array}$ \\
\hline Yeh M, 2002 [82] & $\begin{array}{l}\text { Cited psychometrics reported elsewhere [47,84,85]: } \\
\text { Internal Consistency: } \alpha=0.84-0.96 \text { (good - excellent) } \\
\text { Convergent validity: Russell [89] provided correlations with the NYU Loneliness Scale, } r=0.65 \text { and The Differential Loneliness Scale, } r=-0.72 \\
\text { Concurrent validity: Russell et al. [89] found loneliness scores were related to the experience of affects that have been linked to loneliness (not } \\
\text { specified what these are) } \\
\text { Discriminant validity: Russell et al. [89] demonstrated loneliness scores to be distinct from social desirability, social support, depression, lack of }\end{array}$ \\
\hline
\end{tabular}




\begin{tabular}{|c|c|}
\hline & affiliative motivation, and low social risk taking \\
\hline \multicolumn{2}{|l|}{ 3-item Revised UCLA Loneliness Scale [90] } \\
\hline $\begin{array}{l}\text { Ingram I, Kelly PJ, Deane FP, Baker AL, Raftery DK, } 2018 \\
\text { [22] }\end{array}$ & Internal consistency: $\alpha=0.82$ for study sample (good) \\
\hline $\begin{array}{l}\text { Ingram I, Kelly PJ, Deane FP, Baker AL, Raftery DK, } 2018 \\
\text { [22] }\end{array}$ & 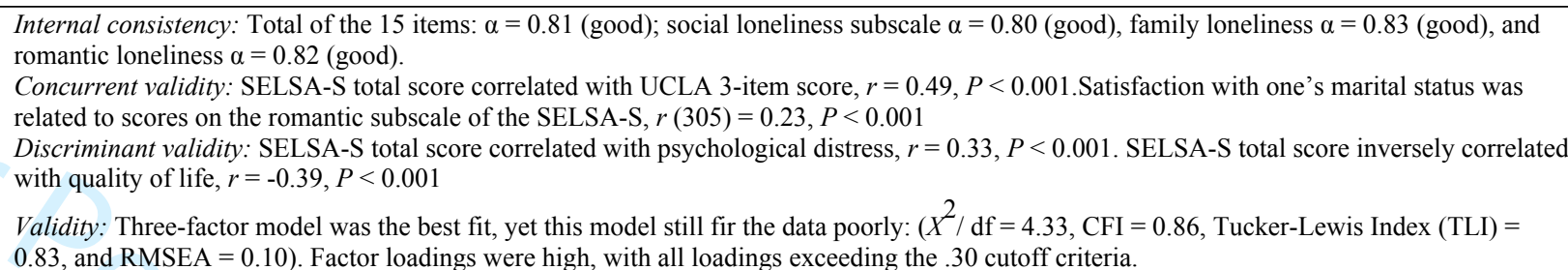 \\
\hline $\begin{array}{l}\text { Hosseinbor M, Yassini ASM, Bakhshani S, Bakhshani S, } \\
2014 \text { [62] }\end{array}$ & $\begin{array}{l}\text { Cited psychomettric properties reported by Jowker [92]: } \\
\text { Internal consistency: } \alpha=0.92 \text { (romantic subscale) (excellent), } \alpha=0.84 \text { (social subscale) (good) and } \alpha=0.78 \text { for (family subscale) (fair). } \\
\text { Cited psychometric properties reported by Ditommaso and Brannen [91] } \\
\text { Internal consistency: } \alpha=0.87-0.89 \text { (good) }\end{array}$ \\
\hline \multicolumn{2}{|l|}{ Bradley Loneliness Scale [93] } \\
\hline \multicolumn{2}{|l|}{ Sisenwein Loneliness Scale [96] } \\
\hline Allen HA, Peterson JS, Whipple S, 1981 [47] & Not reported \\
\hline \multicolumn{2}{|l|}{ Wellbeing Questionnaire developed by Elton and Hornquist [97] } \\
\hline Akerlind, Hornquist, Bjurulf, 1988 [45] & 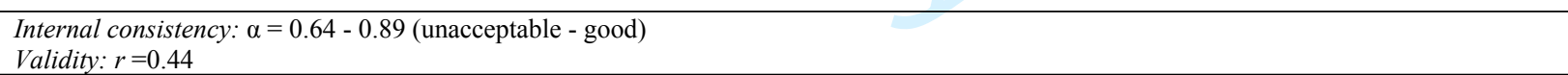 \\
\hline Akerlind I, Hörnquist JO, Hansson B, 1987 [46] & Internal consistency: $\alpha=0.86$ (good) \\
\hline $\begin{array}{l}\text { Akerlind I, Hörnquist JO, } 1989 \text { [32] } \\
\end{array}$ & Internal consistency: $\alpha=0.86$ (good) \\
\hline Elton HL, Hörnquist JO, 1983 [54] & Internal consistency: $\alpha=0.85-0.89$ (good) \\
\hline Hörnquist JO, Elton HF, 1983 [55] & Not reported \\
\hline Hörnquist JO, Akerlind I, 1987 [60] & Internal consistency: $\alpha=0.86$ and $\alpha=0.85$ at two-year re-examination (good) \\
\hline Hörnquist JO, Hansson B, Akerlind I, 1988 [61] & Internal consistency: $\alpha=0.85-0.89$ (good) \\
\hline Loneliness Inventory developed by Woodward [98] & \\
\hline
\end{tabular}




\begin{tabular}{|c|c|}
\hline Medora NP, 1983 [68] & $\begin{array}{l}\text { Internal consistency: } \alpha=0.96 \text { (excellent) } \\
\text { Validity: not reported for this study, yet author alluded to other studies that have established this measure's validity against the Sisenwein } \\
\text { Loneliness Self-Rating Scale [96] }\end{array}$ \\
\hline Medora NP, Woodward JC, 1990 [69] & $\begin{array}{l}\text { Internal Consistency: } \alpha=0.96 \text { (excellent) } \\
\text { Test-retest reliability: } \mathrm{ICC}=0.97 \text { (excellent) } \\
\text { Cited psychometrics reported by Woodward [99]: } \\
\text { Criterion validity: correlation with a single-item self-report measure of loneliness: } r=0.93, P<0.001 \text {. Correlation with UCLA: } r=0.87, P< \\
0.001\end{array}$ \\
\hline Medora NP, Woodward JC, 1991 [70] & $\begin{array}{l}\text { Internal Consistency: } \alpha=0.96 \text { (excellent) } \\
\text { Test-retest reliability: } \mathrm{ICC}=0.97 \text { (excellent) } \\
\text { Cited psychometrics reported by Woodward [99]: } \\
\text { Criterion validity: correlation with a single-item self-report measure of loneliness: } r=0.93, P<0.001 \\
\text { Correlation with UCLA: } r=0.87, P<0.001\end{array}$ \\
\hline \multicolumn{2}{|l|}{ Single Item Measures } \\
\hline $\begin{array}{l}\text { Kuerbis A, Padovano HT, Shao SJ, Houser J, Muench FJ, } \\
\text { Morgenstern J, } 2018 \text { [65] }\end{array}$ & $\begin{array}{l}\text { Not reported. } \\
\text { One item measured loneliness, “In the past hour, how lonely do you feel?" The response set on these items ranged from } 0 \text { (not at all) to } 8 \\
\text { (extremely). }\end{array}$ \\
\hline Li F, Xu Y, Zhu J, Lu J, Zhong B, 2017 [66] & $\begin{array}{l}\text { Not reported. } \\
\text { Loneliness was measured with a single-item self-report question “How often do you feel lonely?" with a five-point scale: } 1 \text { (never), } 2 \text { (seldom), } 3 \\
\text { (sometimes), } 4 \text { (often), } 5 \text { (always). }\end{array}$ \\
\hline Li H, Zhong B, Xu Y, Zhu J, Lu J, 2017 [67] & $\begin{array}{l}\text { Not reported. } \\
\text { Loneliness was measured with a single-item self-report question "How often do you feel lonely?" with a five-point scale: } 5 \text { (never), } 4 \text { (seldom), } 3 \\
\text { (sometimes), } 2 \text { (often), } 1 \text { (always). The authors classified participants as being 'lonely' if they indicated feeling lonely at least 'sometimes'. }\end{array}$ \\
\hline Price RH, Curlee-Salisbury J, 1975 [76] & $\begin{array}{l}\text { Not reported for items related to loneliness. } \\
\text { Loneliness was assessed though a single item that was part of an 8-item scale. The item read: "I felt lonely". }\end{array}$ \\
\hline Yang Y, Xu Y, Chen W, Zhu J, Lu J, Zhong B, 2017 [81] & $\begin{array}{l}\text { Not reported for items related to loneliness. } \\
\text { Loneliness was assessed with a single question asking how often the respondent feels lonely on a 5-point Likert scale: } 1 \text { (always), } 2 \text { (often), } 3 \\
\text { (sometimes), } 4 \text { (seldom), } 5 \text { (never). Participants were classified as lonely if they indicated their loneliness was "sometimes", "often", or } \\
\text { "always", while participants who reported "never" or "seldom" were classified as not lonely. }\end{array}$ \\
\hline Zhong B, Xu Y, Zhu J, Liu X, 2018 [83] & $\begin{array}{l}\text { Not reported for items related to loneliness. } \\
\text { Loneliness was assessed with a single question asking how often the respondent feels lonely on a 5-point Likert scale: } 1 \text { (always), } 2 \text { (often), } 3 \\
\text { (sometimes), } 4 \text { (seldom), } 5 \text { (never). The five category loneliness variable was transformed into a binary variable: lonely ( } \geq 3 \text { ) and not lonely ( } \leq 2) \text {. }\end{array}$ \\
\hline Qualitative studies & (2) \\
\hline Boyles BR, 2018 [49] & Not applicable \\
\hline Funk PE, $1973[58]$ & $\begin{array}{l}\text { Not applicable. Interview question: "Within the framework of the phenomenon of loneliness are there similarities in descriptions of that } \\
\text { phenomenon by some members of the population?" }\end{array}$ \\
\hline Itzick M, Segal JN, Possick C, 2019 [63] & Not applicable \\
\hline Neale J, Tompkins CNE, Strang J, 2018 [72] & Not applicable \\
\hline Schmidt DR, $2002[77]$ & $\begin{array}{l}\text { Not reported for items related to loneliness. Interview question for staff: "Talk to me about the philosophy and approach that Faith Recovery } \\
\text { Center has in addressing the issues of loneliness and social relationships." Loneliness was not explicitly asked of clients. }\end{array}$ \\
\hline
\end{tabular}




\begin{tabular}{|c|l|}
\hline Other measures & \\
\hline $\begin{array}{l}\text { Newton TF, De La Garza R, Kalechstein AD, Tziortzis D, } \\
\text { Jacobsen CA, 2009 [74] }\end{array}$ & $\begin{array}{l}\text { Not reported for items related to loneliness } \\
\text { Loneliness was a category on a questionnaire used to identify self-perceived reasons for taking drugs or for relapsing. The item read: Do you use } \\
\text { drugs mostly to make bad feelings like boredom, loneliness, or apathy go away? Responses ranged from 1 (not at all) to 7 (very much). }\end{array}$ \\
\hline Perodeau GM, du Fort GG, 2000 [75] & $\begin{array}{l}\text { Not reported for items related to loneliness } \\
\text { Older Americans Resources and Services [100]. One of the subjective items on this scale was "feeling lonely" and the scoring procedure } \\
\text { described by Harel and Deimling [101] was used. }\end{array}$ \\
\hline Schonfeld L, Dupree, LW, Rohrer GE, 1995 [78] & $\begin{array}{l}\text { Not reported for items related to loneliness } \\
\text { Loneliness described as a category of 'intrapersonal determinants of drinking' which was devised by the researchers based on classifications } \\
\text { developed previously by Marlatt and Gordon [102,103]. }\end{array}$ \\
\hline Siddique F, Ahmad Mann A, Ali T, 2012 [79] & $\begin{array}{l}\text { Not reported for items related to loneliness } \\
\text { A questionnaire was used which asked about loneliness. Table 3 in the study indicates that participants rated loneliness "To a great extent", "To } \\
\text { some extent", or "Not at all". No information about how the item was framed. }\end{array}$ \\
\hline $\begin{array}{l}\text { Van Hasselt VB, Null JA, Kempton T, Bukstein OG, 1993 } \\
\text { [80] }\end{array}$ & $\begin{array}{l}\text { The Loneliness Scale [104] is a 24-item questionnaire developed to evaluate children's feelings of isolation and social dissatisfaction. Children } \\
\text { indicate on a five-point scale the extent to which each statement is a true description of them. } \\
\text { Cited psychometrics reported by Asher et al. [104]: } \\
\text { Split-half reliability = 0.91 (excellent) }\end{array}$ \\
\hline
\end{tabular}

Note. Internal consistency cutoffs based on Cicchetti (1994) [105]. For information about the validity and reliability of the UCLA Loneliness Scale (Version 3; [51]); The Bradley Loneliness Scale [93], The Sisenwein Loneliness Scale [96] and the Social and Emotional Loneliness Scale for Adults - Short Version [91] across other populations, see Appendix 1. ICC, intraclass correlation coefficient. 